\title{
Askorbik Asit'in Amperometrik Tayini için Esnek, Serbest Duran Nikel Sülfür Temelli Grafen Kağıt Elektrotun Geliştirilmesi
}

\author{
Development of Flexible, Free-Standing Nickel Sulfide Based Graphene Paper Electrode \\ for Amperometric Determination of Ascorbic Acid
}

\author{
Kader DAĞCI KIRANŞAN* \\ Atatürk Üniversitesi, Fen Fakültesi, Kimya Bölümü, Erzurum, 25240, Turkey
}

• Geliș tarihi / Received: 9.05.2019 • Düzeltilerek geliş tarihi / Received in revised form: 1.10.2019 • Kabul tarihi / Accepted: 8.10 .2019

\begin{abstract}
Öz
Esnek, serbest duran ve dayanıklı nikel sülfür/indirgenmiş grafen oksit (NiS/rGO) kompozit kağıt elektrot, rGO kağıt elektrot yüzeyinde NiS yapılarının basit bir elektrokimyasal depozisyonuyla hazırlanmıştır. NiS/rGO kompozit kağıt elektrot taramalı elektron mikroskopisi (SEM), X-ışınları fotoelektron spektroskopisi (XPS), X-ışınları kırınım difraksiyonu (XRD) , Raman spektroskopisi ve elektrokimyasal empedans spektroskopisi (EIS) gibi teknikler kullanılarak karakterize edilmiştir. Hazırlanan NiS/rGO kompozit kağıt, askorbik asitin (AA) elektrokimyasal tayininde kullanılmıştır. NiS/rGO kompozit kağıt elektrot yüzeyinde bulunan top benzeri NiS nano yapılarının, oldukça büyük aktif yüzey alanı sağladığı için kağıt elektrotun katalitik performansını büyük ölçüde artırdığı belirlenmiştir. AA, NiS/rGO kompozit kağıt üzerinde geniş lineer aralıkta $(1.0-800 \mu \mathrm{M})$, düşük tayin limitinde $(0.7 \mu \mathrm{M})$ ve yüksek seçicilikle tayin edilmiştir. Bunun yanı sıra yapılan elektrokimyasal testler sonucu kompozit kağıt elektrodun oldukça kararlı, esnek ve atmosfer koşullarına dayanıklı olduğu ortaya konmuştur.
\end{abstract}

Anahtar kelimeler: Askorbik Asit, Amperometrik Sensör, Grafen Kağıt Elektrot, Nikel Sülfür

\begin{abstract}
The flexible, free-standing and durable highly rough NiS/rGO composite paper electrode was prepared with a simple electrochemical deposition of NiS structures on the surface of the rGO paper electrode. NiS/rGO composite paper electrode was characterized by using scanning electron microscopy (SEM), X-ray photoelectron spectroscopy (XPS), Xray diffraction (XRD), Raman spectroscopy and electrochemical impedance spectroscopy (EIS) techniques. Asprepared NiS/rGO composite paper was used for the electrochemical detection of ascorbic acid (AA). The rough and the ball-like NiS nanostructures on the $\mathrm{rGO}$ paper electrode surface greatly increased the catalytic performance of the paper electrode by providing a large active surface area. AA was detected on NiS/rGO composite paper with a wide linear range from 1.0 to $800 \mu M$, a low detection limit of $0.7 \mu M(S / N=3)$ and a high sensitivity. Besides, the electrochemical tests showed that the composite paper electrode is very stable, flexible and durable at the atmospheric conditions.
\end{abstract}

Keywords: Ascorbic Acid, Amperometric Sensor, Graphene Paper Electrode, Nickel Sulfur

*Kader DAĞCI KIRANŞAN; kdagci@atauni.edu.tr, Tel: (0442) 23144 36, orcid.org/0000-0002-0764-9393 


\section{Giriş}

C vitamini olarak bilinen askorbik asit (AA), enzimatik reaksiyonlar, kollajen sentezi, derinin korunması ve bağışıklık sisteminin gelişimi gibi pek çok biyolojik proseste vücudun normal aktivitelerini sürdürmek için gerekli olan vitaminlerden birisidir (Xie vd., 2019). İnsan vücudunda AA sentezlenemez, bu nedenle vücuda alınımı diyetlere bağımlıdır. Bununla birlikte AA'nın aşırı alımı veya eksikliği ishal, hiperaktivite, bulaşıcı hastalıklar, kanser ve böbrek taşı oluşumu gibi pek çok hastalığın oluşmasına zemin hazırlamaktadır (Chen vd., 2019). Ayrıca antioksijenasyon yeteneğine sahip olan AA lipidlerin, DNA'nın ve proteinlerin oksidatif hasara karşı direnç göstermesinde etkilidir (May vd., 2019).

Birçok çalışma, insan vücudundaki AA seviyesinin parkinson hastalığı, alzheimer hastalığı, kalp-damar hastalıkları ve bazı kanser türleri gibi birçok hastalıkla yakından ilişkili olduğunu göstermiştir (Harraz vd., 2019). Bu nedenle, analitik uygulamalar ve hastalıkların teşhisi için AA miktarının basit, güvenilir, yüksek duyarlılık ve seçiciliğe sahip bir yöntemle tayini büyük önem arz etmektedir. Şimdiye kadar AA tespiti için pek çok yöntem kullanılmıştır, bunlar arasinda; kromatografi (Kablova vd., 2012), kemilüminesans (Wang vd., 2012), kolorimetri (Peng vd., 2015), k1lcal elektroforez (Kim vd., 2002), oksitleyici bir madde ile titrasyon (Chen vd., 2016) ve elektrokimya (Sun vd., 2011; Rather vd., 2017; Thearle vd., 2017) sayılabilir. Bu yöntemler arasında elektrokimyasal yöntemler, genel olarak uygulamalarının kolay ve maliyetsiz olması, yüksek duyarlılık ve seçiciliğe sahip olmaları ve analiz süresinin kısa olması gibi pek çok avantaja sahiptir (Kaplan vd., 2010). Elektrokimyasal yöntemlerin en büyük dezavantaj1 ise analitin elektroaktif olmas1 zorunluluğudur. Yani elektroaktif olamayan türler ile elektrokimyasal çalışma yapılamamaktadır. Fakat AA da elektroaktif bir bileşik (Kumar vd., 2019) olduğuna göre, bu dezavantaj ortadan kalkmakta ve elektrokimyasal yöntemler ile tayini önem kazanmaktadır.

Geçtiğimiz birkaç yıl boyunca, farklı yapısal ve morfolojik özelliklere sahip kağıt benzeri materyaller hazırlanmış ve sensör, süperkapasitör, lityum iyon batarya, membran, ağır metal giderimi, hidrojen ve oksijen oluşum reaksiyonları gibi birçok alanda klasik materyallerin yerini almıştır. Kağıt benzeri materyallerin başında grafen kağıtlar gelmektedir (Topçu vd., 2016).
Grafen oksit (Graphene Oxide, GO), indirgenmiş grafen oksit (reduced Graphene Oxide, rGO) veya grafenden türetilmiş iki boyutlu (twodimensional, 2D) grafen esaslı kağıt materyaller; fizik, malzeme bilimleri, sensör, çevre mühendisliği gibi birçok alanda ilgi odağı haline gelmiştir (Dağc1 ve Alanyalıŏlu, 2016; Dağc1 Kıranşan ve Topçu, 2018). Bunun nedeni, bu tür materyallerin tek tek grafen tabakalarının temel özelliklerini muhafaza etmekle beraber, farklı maddeler ile beraber kullanıldığında kollektif ve sinerjik fonksiyonel özellik göstermeleridir (Dağc1 Kıranşan vd., 2018). Grafen esaslı kağttlar; ince, esnek, şekil verilebilir, kesilebilir özellikleriyle invivo çalışmalar için üstünlük sağlarken, serbest durma özelliğiyle ve her iki yüzünün kullanılması sonucu yüksek akım yoğunluğu ve elektroaktif yüzey alanı sağlamasıyla elektrokimyasal çalışmalarda elektrot olarak etkili bir şekilde kullanılabilmektedir (Topçu ve Dağcı Kıranşan, 2018). Grafen kağıtlar diğer kağıt benzeri materyaller ile karşılaştıııldıklarında, oldukça yüksek esnekliğe, yüksek mekanik ve elektronik performansa sahiptirler.

Grafen esaslı kağıt materyallerin özelliklerinin daha da iyileştirip performanslarının artırılması ile ilgili araştırmalar devam etmektedir. Özellikle grafen esaslı kağıt elektrotların yüzeyleri amaç doğrultusunda farklı elektriksel, yapısal ve morfolojik özelliklere sahip maddeler ile kaplanarak kompozit kağıt elektrotlar hazırlanabilmektedir. $\mathrm{Bu}$ şekilde hazırlanan kompozit kağıt elektrotların, hem grafen kağıtların sahip oldukları yüksek esneklik, mekanik ve elektronik performansina ilave olarak elektrokimyasal ve elektriksel performansını da artırdığı belirlenmiştir (Dağcı Kıranşan vd., 2016)

Pek çok redoksaktif faradaik elektrot materyali arasında, geçiş niteliğindeki metal kalkojenitler, mükemmel yapısal özellikleri ve iyi elektrokimyasal performansları nedeniyle geniş ölçüde araştırılmaktadırlar. $\mathrm{Ni}_{3} \mathrm{~S}_{2}, \mathrm{NiS}_{2}, \mathrm{NiS}$ ve $\mathrm{Ni}_{3} \mathrm{~S}_{4}$ gibi farkl1 fazlara sahip nikel sülfürler (NiS), elektrokimyasal çalışmalarda ileriye doğru umut verici elektrot malzemeleri olarak kabul edilmektedirler (Luo vd.,2017). Bunlar arasında NiS, düşük maliyeti, üstün redoks aktivitesi ve yüksek elektron iletim hızı nedeniyle faradayik elektrotlar olarak geniş çapta araştırılmıştır (Li vd., 2019). Son birkaç yılda, çeşitli morfolojilere sahip NiS yapıları, başta hidrotermal yöntem olmak üzere farklı kimyasal yöntemler kullanılarak sentezlenmiştir (Tran vd., 2018). Fakat NiS yapısının elektrokimyasal olarak bir elektrot yüzeyinde hazırlanması ile ilgili 
çalışmaların sayısı yok denecek kadar azdır. Yüzeyde hazırlanan NiS yapısının sahip olacağ1 üstün elektriksel ve morfolojik özellikler düşünüldüğünde, NiS modifiye yüzeylerin hazırlanması büyük önem arz etmektedir.

Literatür incelendiğinde AA'nın belirlenmesinde genellikle florometrik yöntemlerin kullanıldığ dikkat çekmektedir. $\mathrm{Bu}$ kapsamda özellikle $\mathrm{CuInS}_{2}, \mathrm{CuInSe}_{2}, \mathrm{AgInS}_{2}$ gibi I-III-VI temelli kuantum noktaların (quantum dots, QD) II-VI QD'lere kıyasla daha az toksik oldukları belirlenmiş ve AA tayininde kullanımlarının uygun olduğu rapor edilmiştir (Xie vd., 2019). Farklı bir çalışmada hidrotermal bir yöntem kullanılarak CuInS ${ }_{2}$ QDs hazırlanmıştır ve AA'nın tayininde kullanılmıştır. Deneysel veriler değerlendirildiğinde tayin limiti $50 \mathrm{nM}$ olarak belirlenmiştir (Liu vd., 2018). Farklı bir çalışma grubu tarafindan çevre dostu bir yöntem kullanılarak suda çözülebilen $\mathrm{AgInS}_{2}$ (AIS) QDs hazırlanmıştır. Hazırlanan $\mathrm{AgInS}_{2}$ QDs kullanılarak AA tayini gerçekleştirilmiş ve geniş bir lineer aralık sunduğu belirtilmiştir (May vd., 2019). Suda çözünür floresan karboksil fonksiyonlu CdSe-ZnS QD, grafen oksit (GO) üzerinde immobilize edilmiş ve bu şekilde hazırlanan kompozit yap1 kullanılarak AA'nın sulu çözeltilerde tayini çalışılmıştır. Kompozit yapıda bulunan $\mathrm{ZnS}$ ve CdSe yapılarının katalitik aktiviteyi oldukça artırdığı rapor edilmiştir (Arumugan ve Kim, 2018). Burada farklı yapısal özelliklere sahip QD'ler kullanılarak AA tayini gerçekleştirildiğinde düşük tayin limitlerine ulaşılmasına karşılık, QD sentezlerinin uzun ve zahmetli olması ayrıca toksit olmaları, farklı materyallerin kullanımını cazip hale getirmiştir.

$\mathrm{Bu}$ çalışmada basit bir filtrasyon tekniği kullanılarak rGO kağıt elektrot hazırlandı ve hazırlanan rGO kağıt elektrot yüzeyi dönüşümlü voltametri (Cyclic Voltammetry, CV) tekniği kullanılarak NiS yapısı ile modifiye edildi. Böylece literatürde olmayan NiS/rGO kompozit kağıt elektrot elde edildi. NiS/rGO kompozit kağıt elektrot taramalı elektron mikroskopisi- enerji dağıtıcı X-1şını spektroskopisi (Scanning Electron Microscopy- Energy Dispersive X-ray spectroscopy, SEM-EDS), X-ışınları kırınımı spektroskopisi (X-ray Powder Diffraction, XRD), $\mathrm{X}$-1şınları fotoelektron spektrokopisi (X-ray Photoelectron Spectroscopy, XPS), elektrokimyasal empedans spektroskopisi (Electrochemical Impedance Spectroscopy, EIS) ve Raman spektroskopisi gibi teknikleri kullanılarak karakterize edildi. Hazırlanan NiS/rGO kompozit kağıt elektrot direk olarak
AA'nın amperometrik belirlenmesinde kullanıldı. NiS/rGO kompozit kağıt elektrot kullanılarak AA'nın belirlenmesi için tayin sınırın ve doğrusal çalışma aralığı CV ve amperometri gibi elektrokimyasal teknikler kullanılarak araştırıldı. İlk defa esnek, serbest duran ve dayanıklı NiS/rGO kompozit kağıt elektrotu hazırlanıp AA tayininde kullanıldığı için bu çalışma literatüre katkı sağlayacaktır.

\section{Gereç ve Yöntem}

\subsection{GO'nun Kimyasal Sentezi}

GO'nun, literatürde modifiye Hummers metodu (Hummers ve Offeman, 1958) olarak bilinen iki kademeli bir prosedür ile sentezlenmiştir.

\subsubsection{GO Sentezi için ön Oksidasyon İşlemi}

GO'nun ön oksidasyon işleminde, ilk olarak 12.5 $\mathrm{mL}$ derişik $\mathrm{H}_{2} \mathrm{SO}_{4} 90^{\circ} \mathrm{C}$ 'ye kadar 1sitılmış, $2.5 \mathrm{~g}$ $\mathrm{K}_{2} \mathrm{~S}_{2} \mathrm{O}_{8}$ ve 2.5 g $_{2} \mathrm{O}_{5}$ sicak derişik asit üzerine karıştırılarak eklenmiş ve $80^{\circ} \mathrm{C}^{\prime}$ de çözünmesi sağlanmıştır. Bu karışımın üzerine $3.0 \mathrm{~g}$ grafit tozu yavaşça eklenmiştir. Oluşan baloncuklu ürün çöktükten sonra karışım 5 saat $80^{\circ} \mathrm{C}^{\prime} \mathrm{de}$ bekletilmiş ve bu süre sonunda oda sıcaklığına soğutulan karışıma $500 \mathrm{~mL}$ distile saf su eklenerek seyreltilmiştir. Elde edilen ürün bir gece bekletildikten sonra süzülmüş ve artık kimyasalları uzaklaştırmak için saf su ile birkaç kez yıkanmıştır. Ürünün oda koşullarında bir gece bekletilmesiyle ön oksidasyon işlemi tamamlanmıştır.

\subsubsection{GO Sentezi için İkinci Oksidasyon İşlemi}

Ön oksidasyon işlemi sonrası elde edilen ürün, $0^{\circ} \mathrm{C}^{\prime}$ deki $115 \mathrm{~mL}$ derişik $\mathrm{H}_{2} \mathrm{SO}_{4}$ çözeltisine eklenerek karıştırılmıştır. Üzerine $15 \mathrm{~g} \mathrm{KMnO}_{4}$ yavaş yavaş eklenirken sıcaklığın $10^{\circ} \mathrm{C}$ 'nin üzerine çıkmamasına özen gösterilmiştir. Ekleme işlemi bittikten sonra sıcaklık $35^{\circ} \mathrm{C}$ 'ye çıkarılarak 2 saat reaksiyon gerçekleşmesi sağlanmış ve bu süre sonunda karışım buz banyosuna alınarak sıcaklığın düşmesi sağlanmıştır. Karışım üzerine, sicaklık $50^{\circ} \mathrm{C}$ 'yi geçmeyecek şekilde, $250 \mathrm{~mL}$ saf su eklenmiş ve 2 saat karıştırma işleminden sonra, ürüne $750 \mathrm{~mL}$ saf su ve $12.5 \mathrm{~mL} \% 30^{\prime} \mathrm{luk}(\mathrm{w} / \mathrm{w})$ $\mathrm{H}_{2} \mathrm{O}_{2}$ eklenmiştir. Rengi hardal sarısına dönen ürün bir gün oda sicaklığında bekletilmiştir. Berraklaşan üst kısmı dekante edilerek, sütlü kahverenginde olan alt kısmı süzülmüş ve süzüntü birçok kez 1:10 sulu $\mathrm{HCl}$ çözeltisi ve en son saf su ile yıkanmıştır. Elde edilen ürün atmosfer koşullarında kurutulduktan sonra, içerdiği metal 
safsızlıkları gidermek için 3 hafta diyaliz edilmiştir. Böylece ikinci oksidasyon işlemi tamamlanmış ve grafit oksit hazırlanmıştır. Diyaliz işleminden sonra süzülüp kurutulan grafit oksit katısı, su içerisinde sonikatör yardımı ile disperse edilerek, $1.0 \mathrm{mgmL}^{-1}$ GO sulu dispersiyonu hazırlanmıştır. $\mathrm{Bu}$ homojen $\mathrm{GO}$ dispersiyonunun (Dağcı ve Alanyalığlu, 2016) birkaç ay süre boyunca kararlılı̆̆ını çökme olmaksızın koruduğu bilinmektedir.

\section{2. rGO Kağıdı Hazırlanması}

GO kağıtları hazırlamak için $1.0 \mathrm{mgmL}^{-1}$ derişime sahip $80 \mathrm{~mL}$ GO süspansiyonu, bir nükleoporik polikarbonat membran filtre kağıdı (Whatman; $\varnothing$ = $47 \mathrm{~mm}$; gözenek boyutu, $0.2 \mathrm{um}$ ) üzerinden ultrafiltrasyon vakum hücresi (EZ-Stream) ile filtrelenmiştir. Atmofer koşullarında kurutulduktan sonra membran üzerinden soyularak GO kağıt elde edilmiştir. GO kağıdın kimyasal olarak indirgenmesiyle rGO kağıt hazırlanmıştır. Bu amaç doğrultusunda hazırlanan esnek GO kağıt, \% 57'lik (w/w) hidrojen iyodür (HI) çözeltisi içerisinde 1 saat karanlı ortamda bekletilerek kimyasal indirgeme işlemine tabi tutulmuş, ardından bol miktarda önce etanol ardından su ile yıkanarak atmosfer koşullarında kurutulmuştur. Böylece esnek, kararl1, serbest duran ve iletken olan rGO kağıt hazırlanmıştır.

\subsection{NiS/rGO Kompozit Kağıtların Hazırlanması}

Esnek rGO kağıt elektrodun yüzeyinin NiS ile kaplanması işleminde, $20 \mathrm{~mm} \quad \mathrm{x} \quad 5 \quad \mathrm{~mm}$ boyutlarında kesilen rGO kağıt, bir Pt levha ile bağlantı kurularak üç elektrotlu hücre sisteminde çalışma elektrotu olarak kullanılmıştır. $2.0 \mathrm{mM}$ $\mathrm{NiCl}_{2}$. $6 \mathrm{H}_{2} \mathrm{O}$ (Nikel (II) klorür hekza hidrat) ve $0.2 \mathrm{M} \mathrm{CH}_{4} \mathrm{~N}_{2} \mathrm{~S}$ (tiyoüre) içeren elektrokimyasal çözeltide, $-1200 \mathrm{mV}$ ile $200 \mathrm{mV}$ potansiyelleri arasında $5 \mathrm{mVs}^{-1}$ tarama hızında dönüşümlü voltametri $(\mathrm{CV})$ tekniği kullanılarak rGO kăğt elektrot yüzeyinde NiS nanoyapıları sentezlenmiştir (Huo vd., 2015). Böylece rGO kağıdın yüzeyi NiS yapıları ile kaplanarak NiS/rGO kompozit kağıt elektrot hazırlanmıştır.

\subsection{Kullanılan Elektrokimyasal Çözeltiler}

Tüm kimyasallar analitik reaktif derecede saftır, Sigma-Aldrich'ten satın alındı ve saflaştırılmadan kullanılmıştır. Deneylerde distile su kullanılmıştır. Kullanılan fosfat tampon çözeltisi, $\mathrm{pH}$ değerini ayarlamak için $0.1 \mathrm{M} \mathrm{Na} \mathrm{Na}_{2} \mathrm{HPO} 4$ ve $0.1 \mathrm{M}$ $\mathrm{NaH}_{2} \mathrm{PO}_{4}$ stok çözeltisinin karıştırılmasıyla hazırlanmıştır. Tüm standart AA çözeltileri fosfat tampon çözeltisi içinde hazırlanmıştır ( $\mathrm{pH} 7.0$ ). Tüm elektrokimyasal çalışmalar Erzurum'a ait atmosfer koşullarında (yaklaşık $20^{\circ} \mathrm{C}$ sıcaklık, 0.82 atm basınç ve $\% 20$ nem oranı) gerçekleştirilmiştir.

\subsection{Asorbik Asit Ölçümlerinin Gerçekleştirildiği Materyaller}

Gerçek numuneler AA tayini için iki farklı materyal kullanılmıştır. Bunlardan ilki eczaneden ambalajlı olarak satın alınan \%0.9'luk izotonik sodyum klorür serum çözeltisidir $(100 \mathrm{~mL}$ çözeltide $0.9 \mathrm{~g}$ Sodyum klorür içeren enjeksiyonluk sulu çözelti). Hücre içerisindeki izotonik ortama uygun ortamda gerçek numune analizlerinin gerçekleştirilmesi için izotonik serum çözeltisi kullanılmıştır.

Diğer materyal ise marketten satın alınan, ambalajlı, son kullanma tarihi geçerli ve Türk Gida Kodeksi'ne uygun olan meyve suyu numunesidir. Meyve suyu numunesi ise farklı bir çok organik ve inorganik maddenin bulunduğu ortamda, NiS/rGO kompozit kağıt elektrotun AA'ya seçici olduğunun belirlenmesi amacıyla kullanılmıştır.

\subsection{Kullanulan Cihazlar}

Üç elektrotlu bir hücreye bağlı Epsilon (BASi) ve Gamry (600+) potansiyostat sistemleri ile EIS, $\mathrm{CV}$ ve amperometri deneyleri yapılmıştır. Elektrokimyasal çalışmalarda $20 \mathrm{~mm}$ x $5 \mathrm{~mm}$ boyutlarında kesilerek hazırlanan rGO kağıtlar doğrudan çalışma elektrotu olarak kullanılmıştır. Buna ilave olarak elektrokimyasal hücrede $\mathrm{Ag} / \mathrm{AgCl}$ (doymuş $\mathrm{KCl}$ ) elektrot ve $\mathrm{Pt}$ teli sırasıyla referans elektrotu ve karşit elektrot olarak görev yapmıştır.

AA'nın tayini de amperometrik yöntem kullanılarak gerçekleştirilmiştir. Amperometrik yöntemde, üç elektrotlu elektrokimyasal hücre içerisinde, sabit karıştırma koşulları altında (1000 rpm karıştırma hızında), analit türün yükseltgenme potansiyeli kör numune çözeltisinde bulunan çalışma elektroduna uygulandi. $\mathrm{Bu}$ koşullar altında belli aralıklar ile analit tür ilave edildi. Analit türün artan miktarlarda ilavesiyle akımdaki değişim zamana bağlı olarak belirlendi. "Amperometrik yöntemde" akım-zaman grafiğinden ise "amperomogram" elde edilmiştir.

NiS/rGO kompozit kağıdın morfolojisi ZEISS SIGMA 300 marka SEM-EDS cihazı ile incelenmiştir. Analizler sırasında kullanılan cihaz 
SEM-EDS ile temel kimyasal analiz yapmak içinde uygun bir cihazdır. XRD spektrumları, monokromatize $\mathrm{Cu}$ Ka radyasyonu $(\lambda=1.5406 \AA)$ sahip bir Rigaku TTR III X ışını difraktometresi ile elde edilmiştir. XPS ölçümleri, standart Al X ışın kaynağına sahip bir Spect-Flex spektrometresi ile gerçekleştirilmiştir. Raman spektrumları, oda sicaklığında WITech alpha 300R marka mikroRaman spektrometresi ile elde edilmiştir.

\section{Bulgular ve Tartışma}

NiS/rGO kompozit kağıdın hazırlanma prosedürü Şekil 1'de temsili olarak gösterilmiştir. Öncelikle rGO kağıt daha önceki çalışmalarımıza göre vakum filtrasyon yöntemi kullanılarak hazırlanmıştır (Dağc1 ve Alanyalıoğlu, 2016; Dağc1 Kıranşan vd., 2016). rGO kağıdın oldukça esnek olduğu Şekil 1'de gösterilmiştir.

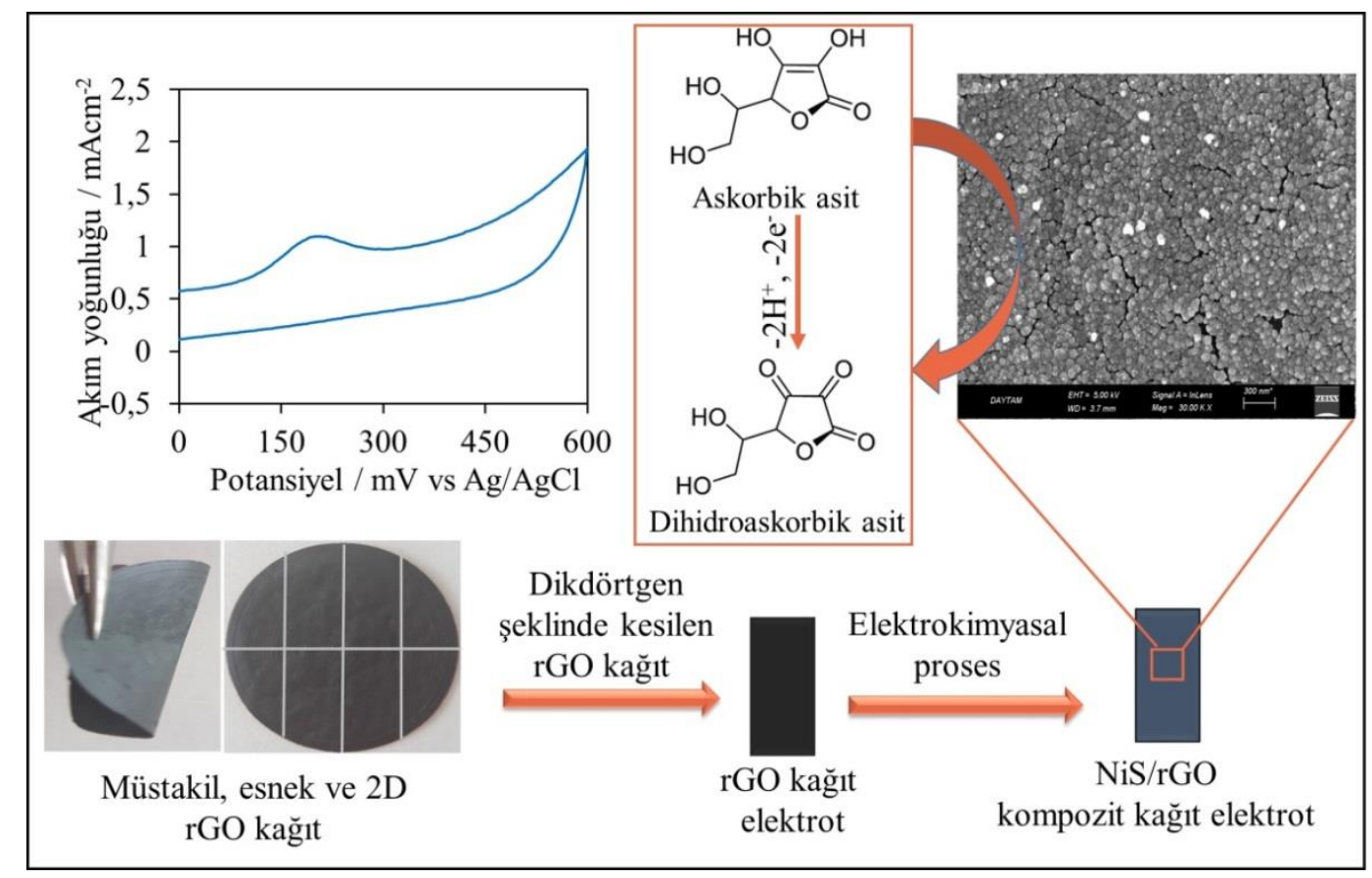

Şekil 1. NiS/rGO kompozit kağıdın şematik üretim prosedürü.

Ardından rGO kağıt çalışma elektrotu olarak kullanılmış ve Nikel klorür ve tiyoüre içeren çözeltide CV tekniği uygulanarak NiS/rGO kompozit kağıt hazırlanmıştır. Hazırlanmış olan NiS/rGO kompozit kağıt yüzeyinde AA'nın elektrokimyasal performansı araştırılmıştır. Hazırlanan kompozit kağıt elektrotun morfolojik karakterizasyonu için FESEM tekniği kullanılmıștır. Şekil 2'de rGO ve serbest duran ve esnek NiS/rGO kağıtlara ait üst yüzey FESEM görüntüleri gösterilmiştir. rGO kağıda ait FESEM görüntüsü (Şekil 2a) incelendiğinde metalik parlak yüzey ve grafen yapısına ait karakteristik kıvrılmış yap1 dikkat çekmektedir. Şekil 2b incelendiğinde ise kağıt elektrot yüzeyinin NiS nanoyapıları ile homojen bir şekilde kaplandığ 1 gözlenmiştir. rGO yüzeyinde yaklaşı $50 \mathrm{~nm}$ boyutunda top benzeri NiS nanoyapılarının oluştuğu belirlenmiştir (Şekil 2c, d). 2 boyutlu rGO kağıt elektrot yüzeyinde oluşan top benzeri $\mathrm{NiS}$ yapılarından dolayı, hazırlanan $\mathrm{NiS} / \mathrm{rGO}$ kompozit kağıdın 3 boyutlu özellik sergileyeceği belirtilmiştir. Böylece NiS/rGO kompozit kağıt elektrodun sahip olduğu büyük aktif yüzey alanından dolayı katalitik çalışmalarda oldukça etkili olacağı öngörülmüştür.

rGO yüzeyinde hazırlanan NiS nanoyapılarının optimum film kalınlığını belirlemek için farklı döngü sayısında hazırlanan NiS/rGO kompozit kağıtlarına ait FESEM görüntüleri Şekil 3'de sunulmuştur. Elde edilen FESEM görüntüleri incelendiğinde 5 döngü sonrası yüzeyde $\mathrm{NiS}$ çekirdeklerinin oluşmaya başladığı gözlenmiştir. 10 döngü sonrası rGO yüzeyinin tamamen yaklaşık $50 \mathrm{~nm}$ boyutunda top benzeri $\mathrm{NiS}$ nanoyapıları ile homojen bir şekilde kaplandığ1 gösterilmiştir. Döngü sayısı 15'e çıkarıldığında ise yüzeyinin tamamen ve yığıı bir şekilde NiS yapıları ile kaplandığı belirlenmiştir. Bu sonuçlar değerlendirildiğinde yüzeyde en düzenli nanoyapıların 10 döngü sonrası elde edildiği belirlenmiş ve daha sonraki çalışmalarda 10 döngü ile hazırlanan NiS/rGO kompozit kağıtlar kullanılmıştır. 


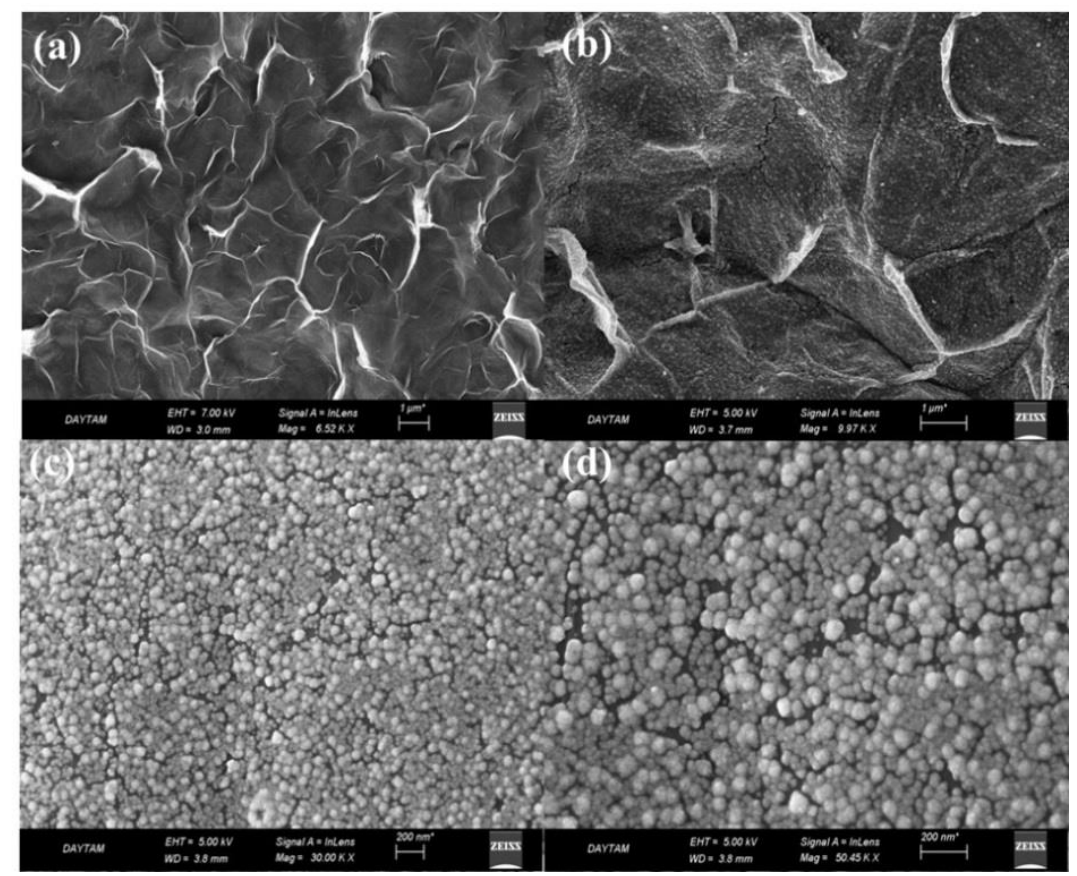

Şekil 2. rGO kağıda (a), NiS/rGO kompozit kağıda (b), düşük (c) ve yüksek (d) çözünürlükte NiS nanotoplarına ait FESEM görüntüleri.

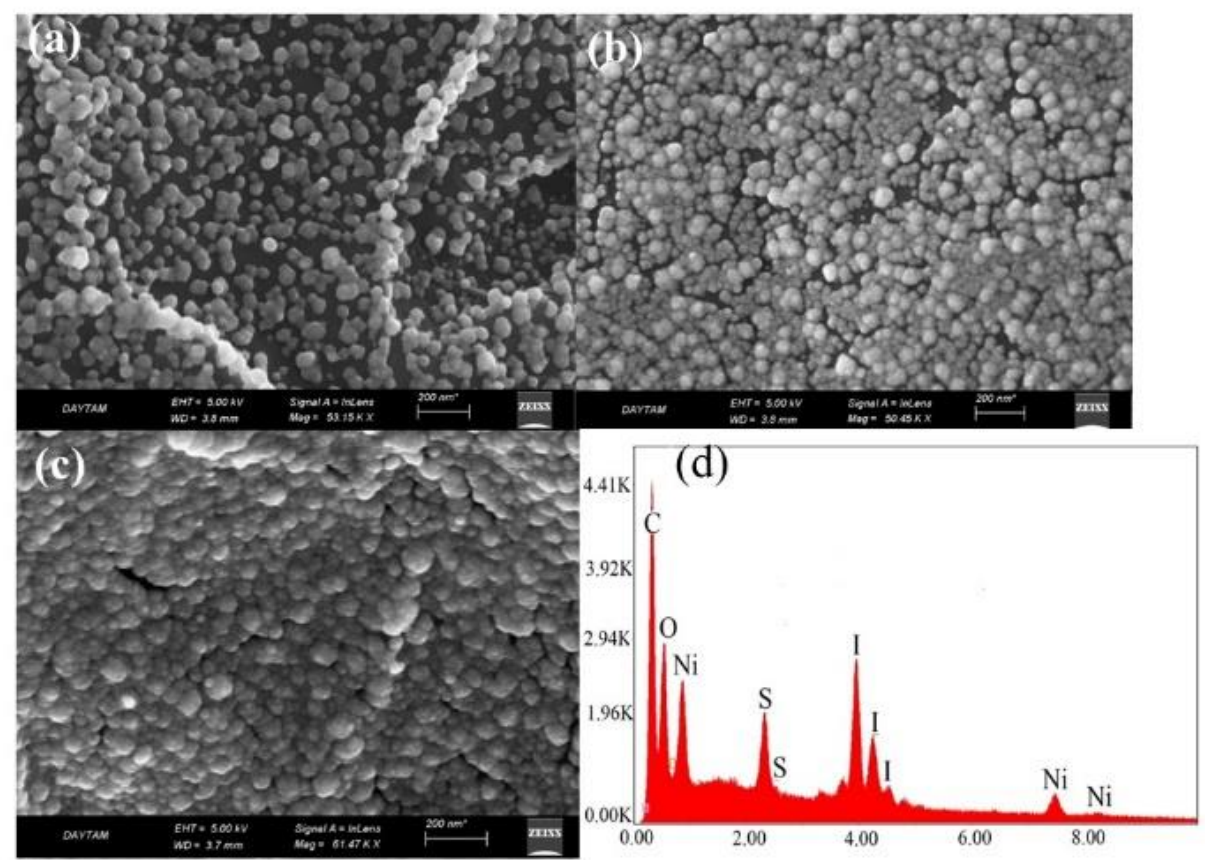

Şekil 3. $2.0 \mathrm{mM} \mathrm{NiCl}$. $6 \mathrm{H}_{2} \mathrm{O}$ ve $0.2 \mathrm{M} \mathrm{CH}_{4} \mathrm{~N}_{2} \mathrm{~S}$ içeren çözeltide, $-1200 \mathrm{mV}$ ile $200 \mathrm{mV}$ potansiyelleri arasında, (a) 5, (b) 10 ve (c) 15 döngü ile hazırlanan NiS/rGO kompozit kağıtlara ait yüzey FESEM görüntüleri, (d) NiS/rGO kompozit kağıdına ait EDX spektrumu. Tarama hızı:5 mVs ${ }^{-1}$

NiS/rGO esnek kağıda ait EDS spektrumu Şekil 3.d'de gösterilmiştir. EDS spektrumu incelendiğinde 0.27 ve $0.56 \mathrm{keV}$ 'da sirasıyla karbon (\%61.91) ve oksijen (\%20.30) atomlarının $\mathrm{K} \alpha$ enerjilerine karşılık gelen piklerin oluştuğu belirlenmiştir. Karbon ve oksijen atomlarına ilave olarak GO kağıt elektrodun kimyasal olarak HI içerisinde indirgenmesinden kaynaklanan I elementinin de varllğg 1 dikkate değerdir. Ayrıca
rGO kağıt üzerinde oluşturulan NiS yapısından kaynaklı Ni (\%6.67) ve S (\%8.08); 0,8 ve $1.2 \mathrm{keV}$ $\mathrm{K} \alpha$ enerjilerine karşl1ık gelen piklerin oluştuğu belirlenmiştir. $\mathrm{Bu}$ piklerin oluşumu rGO kağıt elektrot yüzeyinde NiS nano yapısının oluştuğunu desteklemektedir.

rGO kağıdın ve NiS/rGO kompozit kağıdın kristal yapılarını belirleyebilmek için XRD tekniği 
kullanılmıştır (Şekil 4). rGO kağıda ait XRD spektrumu incelendiğinde $25.4^{\circ}$ 'de grafen yapılarının karakteristik (002) kristal kırınımına karşılık gelen pikin oluştuğu belirlenmiştir. NiS/rGO kompozit kağıdına ait XRD spektrumu incelendiğinde rGO'ya ait kırınım pikine ilave olarak yaklaşık $29.8^{\circ}, 35.5^{\circ}, 35.7^{\circ}, 41.4^{\circ}, 43.2^{\circ}$, $50.2^{\circ}, 50.8^{\circ}, 52.4^{\circ}, 58.3^{\circ}$ ve $61.9^{\circ} 2 \theta$ değerlerinde NiS'nin sirasiyla (101), (300), (021), (220), (221), (131), (321), (410), (401) ve (330) kırınımlarına karşılık gelen piklerin oluştuğu gösterilmiştir (JCPDS card No: 12-0041) (Ma vd., 2015). Bu durum NiS/rGO kompozit kağıdın başarılı bir şekilde hazırlandığınıgöstermektedir.

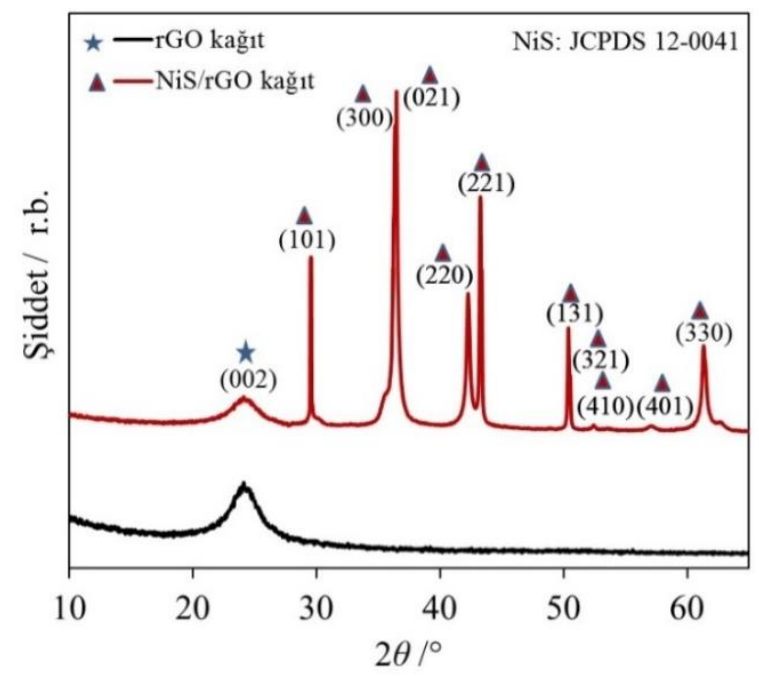

Şekil 4. rGO kağıt ve NiS/rGO kompozit kağıdına ait XRD spektrumları.

rGO ve NiS/rGO kağıtlara ait Raman spektrumları Şekil 5'de gösterilmiştir. rGO kağıda ait Raman spektrumu incelendiğinde $1610 \mathrm{~cm}^{-1}$ dalga sayısında iki boyutlu hegzagonal $\mathrm{C}=\mathrm{C} \quad \mathrm{sp}^{2}$ yapısının E2g geometrisine karşılık gelen $\mathrm{G}$ bandı gözlenmiştir. Buna ilave olarak yaklaşık $1365 \mathrm{~cm}^{-}$ ${ }^{1}$ dalga sayısinda grafen tabakalarının kusurlarından kaynaklanan D bandı oluşmuştur. $\mathrm{NiS} / \mathrm{rGO}$ kompozit kağıdına ait Raman spektrumunda ise D ve G bantlarına ek olarak 110 ile $720 \mathrm{~cm}^{-1}$ dalga sayısı aralığında NiS yapısına karşıllık gelen piklerin oluştuğu belirlenmiştir ve iç şekil olarak sunulmuştur (Salavati-Niasari vd., 2010). Böylece rGO kağıt elektrot yüzeyine NiS yapısının başarılı bir şekilde depozit edildiği gösterilmiştir. Grafen esaslı kağıtların yüzey kusurlarını belirlemek için $D$ ve $G$ bantlarının şiddet oranları kullanılmaktadır (Aksu ve Alanyalığlu, 2017). rGO ve NiS/rGO kağıtlara ait Raman spektrumlarında $\mathrm{I}_{\mathrm{D}} / \mathrm{I}_{\mathrm{G}}$ oranları sirasiyla 1.52 ve 1.05 olarak belirlenmiştir. NiS/rGO ait $\mathrm{I}_{\mathrm{D}} / \mathrm{I}_{\mathrm{G}}$ oranının $\mathrm{rGO}$ kağıda göre düşük olması, grafen kağıdın yüzey kusurlarının kısmen de olsa NiS yapılarının depozisyonu sonucu azaldığına işaret etmektedir. Bu durumda rGO yüzeyinin NiS yapıları ile kaplandığını göstermektedir.

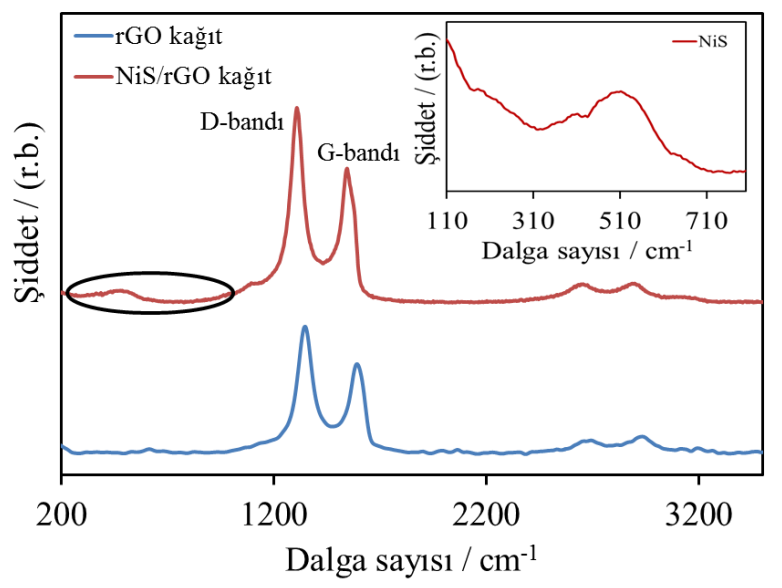

Şekil 5. rGO kağıdına and NiS/rGO kompozit kağıdına ait Raman spektrumları. İç şekil: NiS/rGO kompozit kağıdın 110 ve $720 \mathrm{~cm}^{-1}$ dalga sayısı aralığına ait Raman spektrumu.

Hazırlanan NiS/rGO kompozit kağıdına ait kimyasal yap1 analizi için XPS yöntemi kullanılmıştır. Şekil 6'da NiS/rGO kompozit kağıdına ait XPS spektrumu sunulmuştur. Elde edilen genel XPS spektrumunda kimyasal yapıda $\mathrm{C}, \mathrm{O}, \mathrm{Ni}, \mathrm{S}$ ve I atomlarının varlığ 1 gözlenmiştir (Şekil 6a). Hazırlanan NiS/rGO kompozit kağıt elektrodun \%60.03 C, \%21.65 O, \%6,88 Ni, $\% 8.99 \mathrm{~S}$ ve $\% 2.46$ I atomlarını içerdiği belirlenmiştir. NiS/rGO kompozit kağıdına ait spektrumdaki, maksimum pik pozisyonu $283.7 \mathrm{eV}$ olan $\mathrm{C} 1$ s piki fit edildiğinde, $\mathrm{C}-\mathrm{O}, \mathrm{C}-\mathrm{O}-\mathrm{H}$ ve $\mathrm{H}-\mathrm{O}-$ $\mathrm{C}=\mathrm{O}$ kimyasal bă yapılarına, maksimum pik pozisyonu $531.9 \mathrm{eV}$ olan $\mathrm{O} 1 \mathrm{~s}$ piki fit edildiğinde ise $\mathrm{C}-\mathrm{O}$ ve $\mathrm{C}-\mathrm{OH}$ bağlanmalarına sahip piklerin oluştuğu gösterilmiştir (Şekil 6b,c). Yüzeyde sentezlenen S yapılarına ait XPS spektrumu incelendiğinde; 162.5 ve $67.5 \mathrm{eV}$ değerlerinde sirasıyla $S 2 p_{3 / 2}$ ve $S 2 p_{1 / 2}$ bağlanma enerjilerine karş1lik gelen piklerin oluştuğu belirlenmiştir. Buna ilave olarak $\mathrm{Ni}$ elementine ait XPS spektrumu incelendiğinde ise farklı kimyasal çevrelerden dolayı farklı bağlanma enerjilerine sahip $\mathrm{Ni} 2 \mathrm{p}_{3 / 2}$ ve $\mathrm{Ni} 2 \mathrm{p}_{1 / 2}$ piklerinin oluştuğu gösterilmiştir (Şekil 6.e). Kimyasal yapıda bulunan I ise rGO kağıt elektrot hazırlanırken kimyasal indirgeme işlemi sırasında kullanılan $\mathrm{HI}$ 'dan kaynaklanmaktadır. $\mathrm{Bu}$ veriler doğrultusunda elde edilen XPS sonuçları, EDS sonuçları ile uyumlu olup tasarlanan kompozit kağıt elektrodun istenilen kompozisyonda ve başarılı bir şekilde hazırlandığını ortaya koymuştur. 

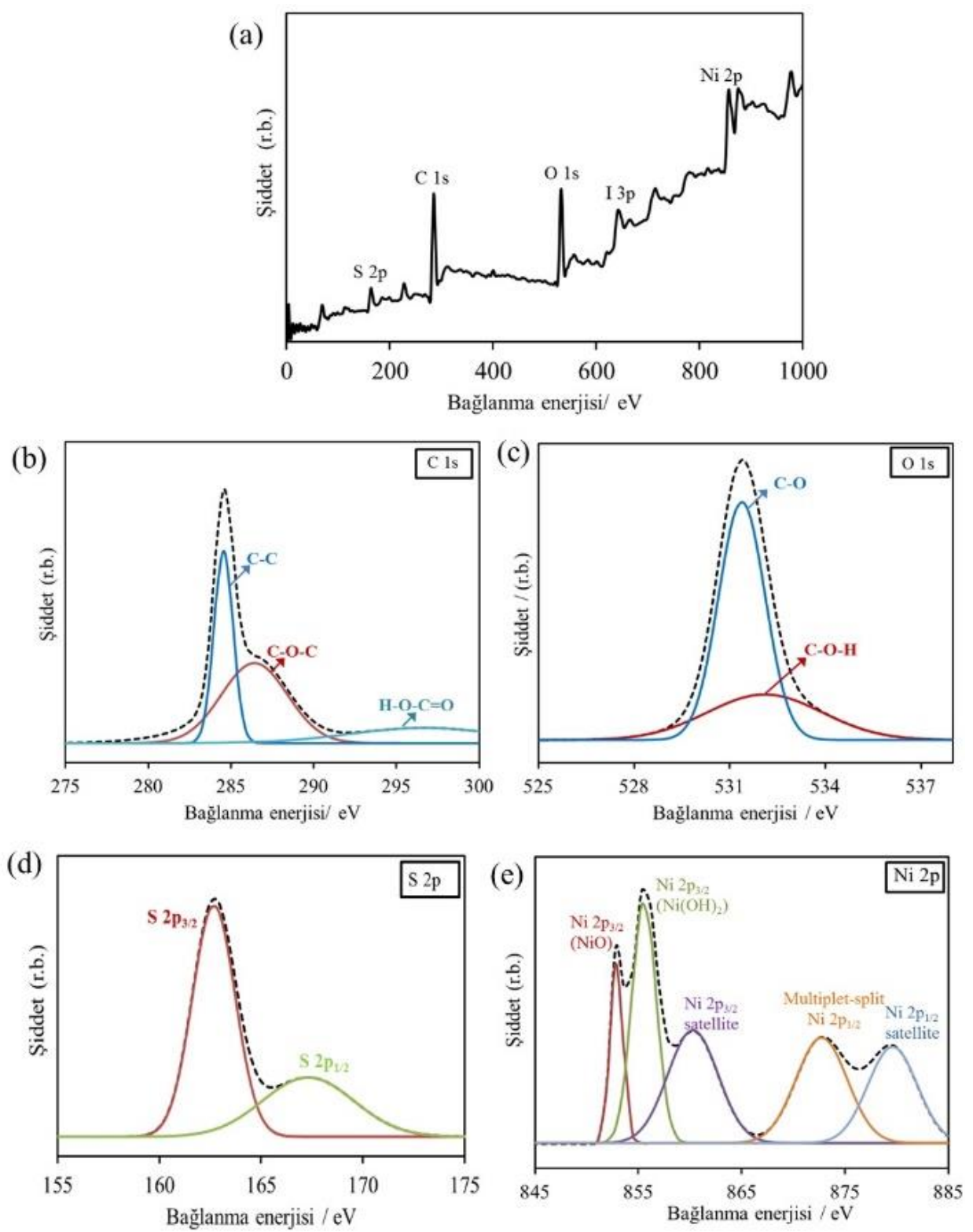

Şekil 6. NiS/rGO kompozit kağıdın: (a) genel, (b) C 1s, (c) O 1s, (d) S 2p ve (e) Ni 2p elementlerine ait XPS spektrumlar1.

Elektrokimyasal çalışmalarda elektrodun arayüzey özellikleri hakkında bilgi almak için kullanılan en iyi yöntemlerden birisi EIS'dir. Eşit molarda $\left[\mathrm{Fe}(\mathrm{CN})_{6}\right]^{3-/ 4-}$ içeren $0,1 \mathrm{M} \mathrm{KCl}$ çözeltisinde, rGO ve $\mathrm{NiS} / \mathrm{rGO}$ kağıt elektrotlar için elde edilmiş Nyquist grafikleri Şekil 7'de gösterilmiştir. Nyquist grafikleri iç şekilde verilen elektriksel devreye göre fit edilmiştir. Burada faradayik yük transfer direnci (Rp), oluşan yarım dairenin çapına karşılık gelmektedir. Çözelti direnci $(\mathrm{Ru})$ ise grafiğin Real Z' eksenini kesim noktasıdır. sabit faz elemanı (CPE) ise çift tabakanın kapasitansıdır. rGO ve NiS/GO kağıtlar için elektron transfer dirençleri sırasıyla 224 ve $80 \Omega$ olarak belirlenmiştir. NiS/rGO kompozit kağıdın elektron transfer direncinin rGO'ya göre oldukça düşük olması, yüzeyde bulunan NiS yapılarının elektron transferini kolaylaştırmasından kaynaklanmaktadır. NiS nanoyapısında bulunan boş $\mathrm{d}$ orbitallerinde elektron kolaylıkla hareket edebildiği için elektron transferi daha kolay gerçekleşebilmektedir (Topçu ve Dağcı Kıranşan, 2018).

Hazırlanan kağıt elektrotlar üzerinde AA'nın elektrokimysal davranışı $\mathrm{CV}$ tekniği kullanılarak incelenmiştir. $1.0 \mathrm{mM}$ AA içeren $0,1 \mathrm{M} \mathrm{pH} 7.0$ fosfat tampon çözeltisinde 0 ile $600 \mathrm{mV}$ potansiyel aralığında elde edilmiş voltamogramlar Şekilde 8'de gösterilmiştir. Literatürde konu ile ilgili yapılan çalışmalardaki voltamogramlar incelendiğinde $\mathrm{rGO}$ elektrot yüzeyinde yaklaşık $350 \mathrm{mV}$ potansiyel değerinde oluşan oksidasyon pikinin AA'nın dönüşümsüz oksidasyonuna 
karşılık geldiği belirtilmiştir (Chen vd., 2019). Bu çalışmada ise AA'nın elekrokimyasal cevabının $\mathrm{NiS} / \mathrm{rGO}$ kompozit kağıt elektrot üzerinde 1.01 $\mathrm{mA} \mathrm{cm}{ }^{-2}$ akım yoğunluğunda ve $220 \mathrm{mV}$ potansiyel değerinde oluştuğu belirlenmiştir.

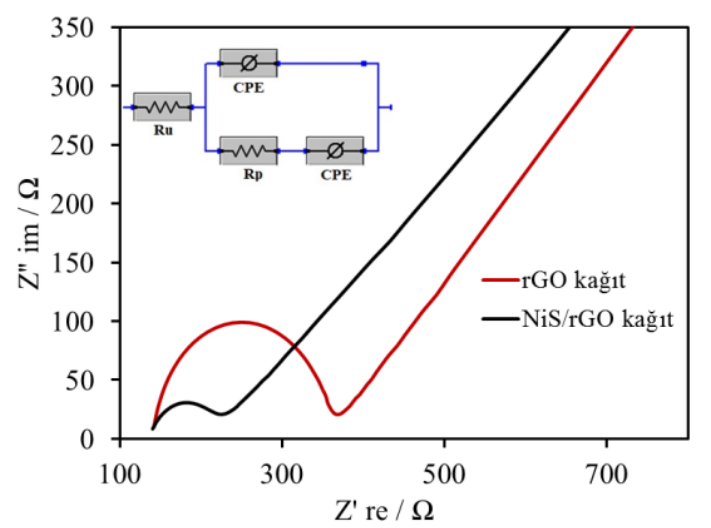

Şekil 7. $0.1 \mathrm{M} \mathrm{KCl}, 1,0 \mathrm{mM} \mathrm{K} \mathrm{K}_{3} \mathrm{Fe}(\mathrm{CN})_{6}$ ve 1.0 $\mathrm{mM} \mathrm{K}_{4} \mathrm{Fe}(\mathrm{CN})_{6}$ içeren çözeltide $\mathrm{rGO}$ kağıt ve NiS/rGO kompozit kağıt elektroda ait Nyquist eğrileri. İç şekil: Kullanılan eşdeğer devre modeli. Frekans değişim: $0.1-10^{5} \mathrm{~Hz}$.

rGO elektrot ile karşıllaştırıldığında NiS/rGO kompozit kağıt elektrotun yaklaşık $130 \mathrm{mV}$ daha düşük potansiyel değerinde ve yaklaşık 10 kat daha yüksek akım yoğunluğunda elektrokimyasal cevap oluşturduğu belirlenmiştir.
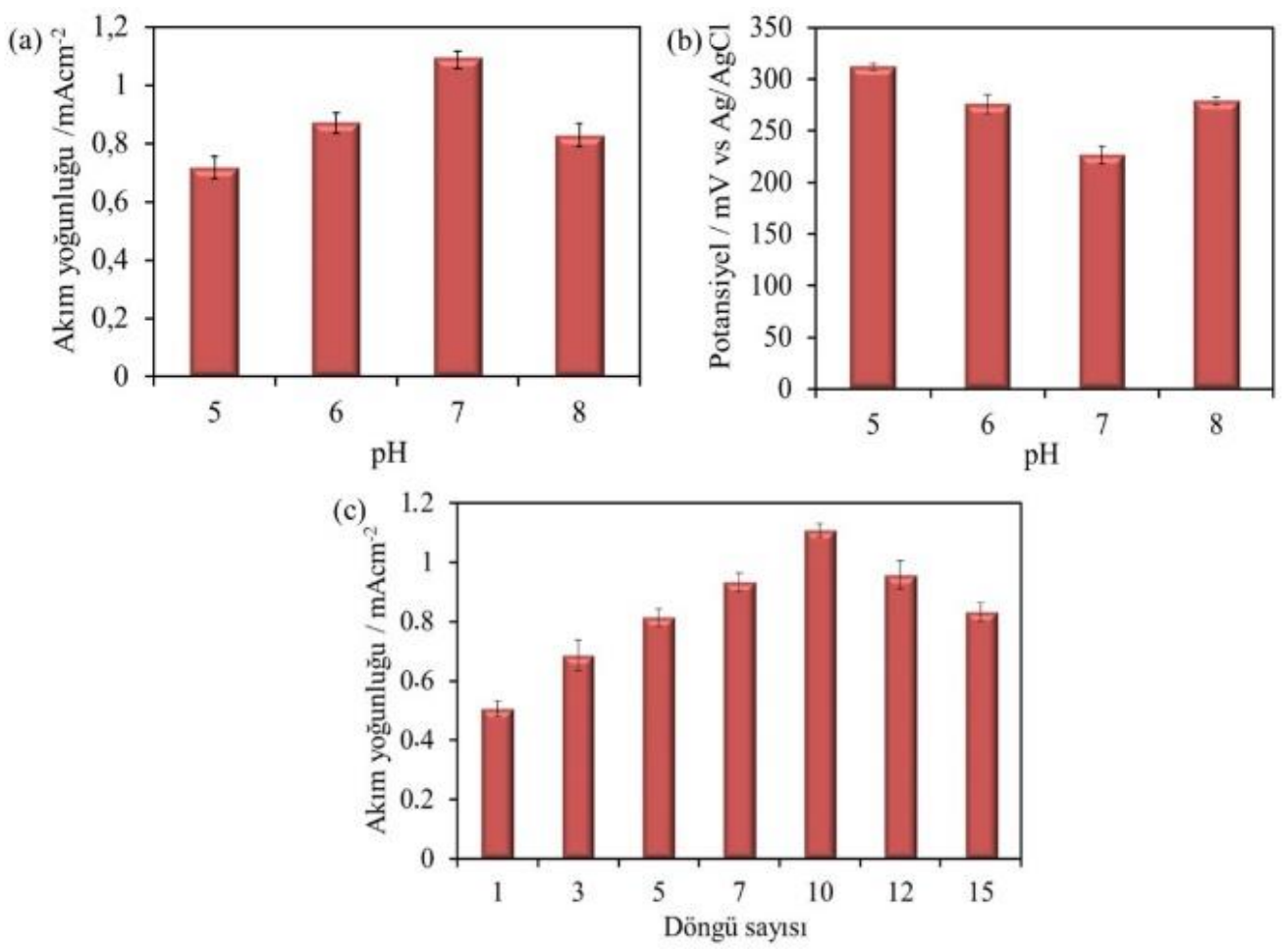

Şekil 9. 1,0 mM AA'in NiS/rGO kompozit kağıt elektrot kullanılarak belirlenen pik akım yoğunluğu (a), ve anodik pik potansiyeli (b) üzerine analit çözeltisinin $\mathrm{pH}$ değerinin etkisi. 1,0 mM AA'nın pik akım yoğunluğu üzerine farklı döngü sayısı ile hazırlanan NiS/rGO kompozit kağıt elektrotlar kullanılarak elde edilmiş akım yoğunluğu- zaman grafiği (c). 
Elektrokatalitik çalışmalarda, katalitik performansı etkileyen önemli faktörlerden biri de analit çözeltisinin $\mathrm{pH}$ değeridir. $\mathrm{Bu}$ kapsamda öncelikle NiS/rGO kompozit kağıt elektrot üzerinde AA'nın hangi $\mathrm{pH}$ değerinde en iyi katalitik performansı sergilediği belirlenmiştir. 0.1 $\mathrm{M}$ fosfat tampon çözeltisi içerisinde farklı $\mathrm{pH}$ değerlerinde ( $\mathrm{pH}$ 5.0, 6.0, 7.0, ve 8.0) elde edilmiş akım yoğunlukları ve potansiyel değerleri Şekil 9.a ve b'de gösterilmiştir. Elde edilen grafikler incelendiğinde, NiS/rGO kompozit kağıt elektrot üzerinde AA için en iyi katalitik performansı, en yüksek oksidasyon akım yoğunluğu $\left(1.01 \mathrm{mAcm}^{-}\right.$ ${ }^{2}$ ) ve en düşük potansiyel değeri $(220 \mathrm{mV})$ ile $\mathrm{pH}$ 7.0'de sergilediği görülmüştür. Daha sonra gerçekleştirilen bütün elektrokimyasal çalışmalar pH 7.0 tampon ortamında gerçekleştirilmiştir. AA'nın elektrokatalitik performansına etki eden diğer bir parametre ise rGO yüzeyine elektrokimyasal olarak kaplanan NiS yapısının film kalınlığıdır. rGO kağıt elektrot yüzeyinde farklı depozisyon süreleriyle hazırlanan NiS/rGO kompozit kağıt elektrotlar kullanılarak AA'nın elektrokatalitik performansı incelenmiş ve sonuçlar Şekil 9.c'de sunulmuştur. Elde edilen grafik incelendiğinde en iyi katalitik performansın 10 döngü sayısı ile hazırlanan NiS/rGO kompozit kağıt elektrot üzerinde gerçekleştiği anlaşılmıştır. 10 döngü sayısına kadar kağıt elektrodun yüzey alanının ve yüzeyde bulunan elektroaktif grupların artmasına bağlı olarak elektrokimyasal aktivite artmıştır. 10 döngüden sonra ise elektrokimyasal aktivite azalmaya başlamıştır. NiS/rGO kompozit kağıt elektrot yüzeyinde elektron transfer hizına etki eden parametreler hem yüzeyde bulunan NiS nanoyapıları hem de rGO kağıt elektrot yüzeyidir. Çünkü rGO kağıt elektrot yüzeyi de aktif bir yüzeyidir. Fakat NiS yapıları yüzeye kaplandıkça hem kendileri elektroaktif oldukları için elektron transferinin hızlanmasina yardımcı olurlar hem de rGO elekrot yüzeyinde birikerek yüzey alanını artırdıkları için elektrokimyasal aktiviteyi artırmaktadırlar. Fakat yüzeyde fazla yığın haline geldiklerinde, rGO yüzeyi ile elektron transferini engelledikleri ve yüzeyde metal yoğunluğunun artmasına bağlı olarak elektron transferinin azalmaya başladığı şeklinde yorumlanmaktadır. $\mathrm{Bu}$ sebeplerden dolayı optimum kaplama miktarı 10 döngü olarak belirlenmiştir.

Amperometrik çalışmalar 10 döngü ile hazırlanan $\mathrm{NiS} / \mathrm{rGO}$ kompozit kağıt elektrot üzerinde $\mathrm{pH}$ değeri 7.0 olan $0.1 \mathrm{M}$ fosfat tampon çözeltisinde $220 \mathrm{mV}$ sabit potansiyelde $1000 \mathrm{rpm}$ karıştırma hızında gerçekleştirilmiştir. AA'nın art arda ilavesi sonucu elde edilen akım-zaman grafiği Şekil 10a'da gösterilmiştir. (a)

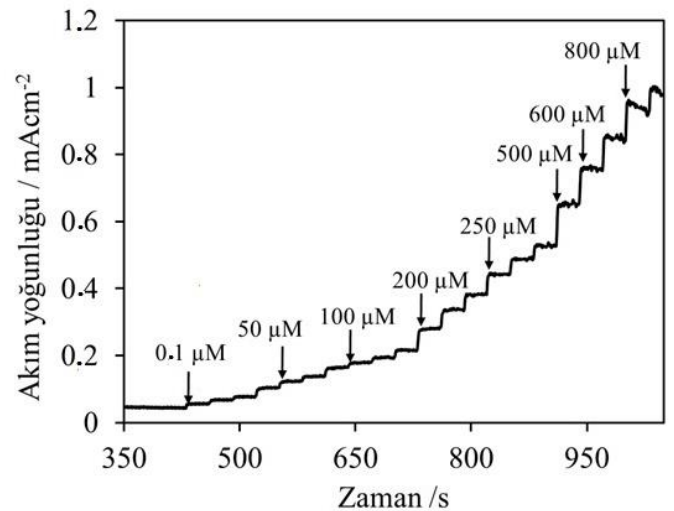

(b)

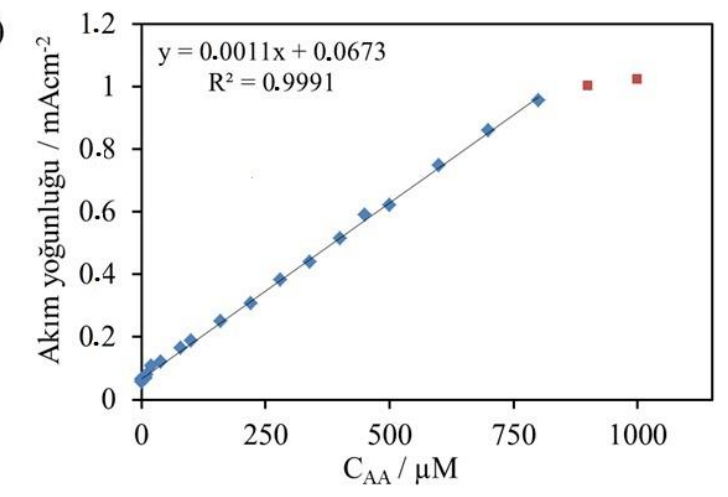

Şekil 10. (a) NiS/rGO kompozit kağıt elektrot kullanilarak $10 \quad \mathrm{~mL} \quad 0.1 \quad \mathrm{M}$ fosfat tampon çözeltisine (pH 7.0 ) ardışık AA ilaveleri ile elde edilen AA'nın elektrokatalitik oksidasyonuna karşılık gelen akım yoğunluğu-zaman grafiği (b) Akım-zaman grafiğinden türetilen kalibrasyon eğrisi. Uygulanan potansiyel: $220 \mathrm{mV}$, karıştırma hizı: $1000 \mathrm{rpm}$

AA ilavesinden sonra akım yoğunluğunun hızlı bir şekilde arttı̆̆ ve ardından sabit kaldığ gözlenmiştir. Bunun sonucu olarak da NiS/rGO kompozit kağıt elektrodun AA'nın elektrokatalitik oksidasyonuna oldukça hızlı cevap verdiği belirlenmiştir. Şekil 10a'dan elde edilen kalibrasyon grafiği Şekil 10b'de gösterilmiştir. Kalibrasyon grafiği incelendiğinde $\mathrm{NiS} / \mathrm{rGO}$ kompozit kağıt elektrodun AA'nın elektrokatalitik oksidasyonuna 1.0-800 $\mu \mathrm{M}$ aralığında lineer cevap verdiği belirlenmiş̧tir. Kalibrasyon eğrisi için eşitlik $\mathrm{j}\left(\mathrm{mAcm}^{-2}\right)=0.0011 \mathrm{C}_{\mathrm{AA}}(\mu \mathrm{M})+0.0673$ ve korelason katsayıs1 0.9991 olarak hesaplanmıştır. Metodun duyarlılığ 0.0011 $\mathrm{mA} \mu \mathrm{M}^{-1} \mathrm{~cm}^{-2}$, tayin limiti ( $\mathrm{S} / \mathrm{N}=3$ için) ise $7 \times 10^{-7}$ $\mathrm{M}$ olarak hesaplanmıştır.

Hazırlanan NiS/rGO kompozit kağıt elektrodun esnekliğini test etmek için, eğilen-bükülen elektrot üzerinde AA'nın elektrokatalitik performans1 değerlendirilmiş ve sonuçlar Şekil 11a'da sunulmuştur. 180 derece, 50 ve $100 \mathrm{kez}$ eğilmebükülme sonrası başlangıç akım cevabının sirasiyla sadece $\% 8$ ve $\% 15$ azaldığ belirlenmiştir. $\mathrm{Bu}$ sonuçlar, hazırlanan esnek ve 
serbest duran kağıt elektrodun özellikle in-vivo uygulamalar için uygun olduğunu göstermiştir. AA'nın elektrokatalitik olarak belirlenmesinde, $\mathrm{NiS} / \mathrm{rGO}$ kompozit kağıt elektrodun mekanik ve fiziksel kararlılı̆g test edilmiştir. AA'nın elektrokatalitik belirlenmesinde NiS/rGO kompozit kağıt elektrot aynı gün içerisinde 10, 30 ve 100 kere kullanıldığında başlangıç akım cevabını sirasiyla $\% 98, \% 95$ ve $\% 85$ koruduğu belirlenmiştir (Şekil 11b). Bu durum hazırlanan NiS/rGO kompozit kağıt elektrodun AA'nın elektrokatalitik belirlenmesinde oldukça yüksek tekrar kullanım kararlılığına sahip olduğunu göstermiştir. AA'nın elektrokatalitik belirlenmesi için hazırlanan NiS/rGO kompozit kağıt elektrodun atmosfer koşullarında depolanma kapasitesi test edilmiş ve 5 . ve 20 . gün sonunda başlangıç akım değerlerini sırasıyla $\% 95$ ve $\% 88$ koruduğu Şekil 11c'de gösterilmiştir. Bu durum sensörün atmosfer koşullarında uzun süre kararlı kalabildiğini göstermiştir. Hazırlanan NiS/rGO kompozit kağıt elektrodun yeniden üretilebilirliğini test etmek için aynı koşularda farklı kompozit kağıtlar hazırlanmış ve AA'nın elektrokatalitik belirlenmesinde kullanılmıştır (Şekil 11d). Sonuçlar değerlendirildiğinde yüzde relatif standart sapmanın (\%RSD) 0.2 olduğu belirlenmiştir. Böylece NiS/rGO kompozit kağıt elektrodun basit bir metot kullanılarak tekrar tekrar üretilebileceği belirlenmiştir.
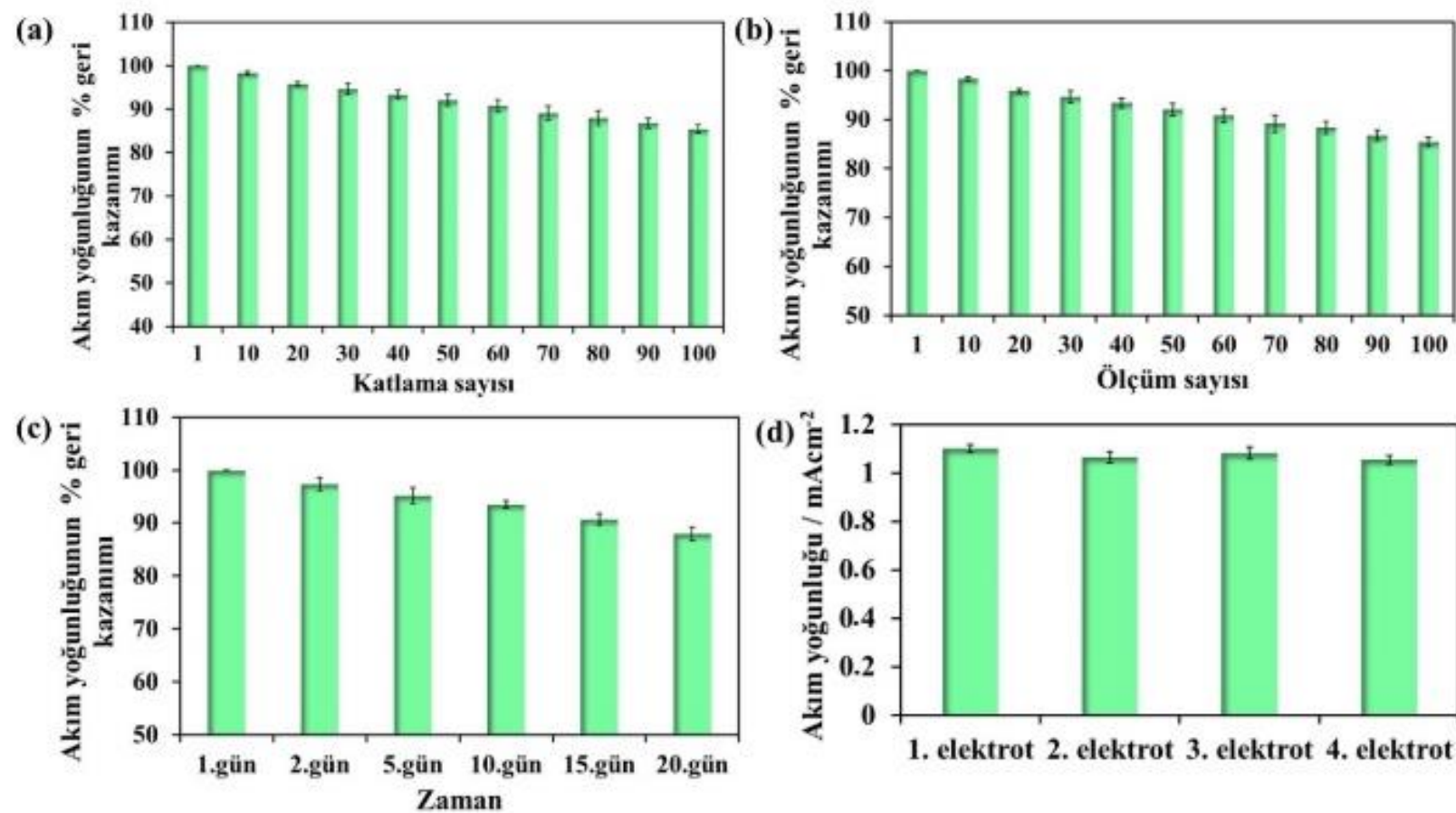

Şekil 11. AA'nın amperometrik belirlenmesinde NiS/rGO kompozit kağıt elektrotun (a) esneklik; (b) tekrar kullanılabilirlik; (c) zamana bağlı kararlılığı ve (d) yeniden üretilebilirlik test sonuçlarını gösteren grafikler.

NiS/rGO kompozit kağıt elektrodun, AA'nın amperometrik belirlenmesinde ne ölçüde seçici olduğunun belirlenmesi için, girişim yapan farklı türlerin varlığında amperometrik çalışma gerçekleştirilmiştir. AA'nın ve girişim yapan diğer türlerin art arda ilavesiyle $(0.1 \mathrm{M} \mathrm{pH} 7.0$ fosfat tampon çözeltisine) elde edilen amperometrik akım-zaman grafiği Şekil 12a'da gösterilmiştir. Amperamogram incelendiğinde, her bir AA enjeksiyonundan sonra akım cevabının oluştuğu, fakat AA'dan 10 kat daha derişik olan diğer türler ilave edildiğinde ise herhangi bir akım cevabının oluşmadığı gözlenmiştir. Fakat dopamin ilavesinden sonra akım artışının olduğu gözlenmiştir. Bunun sebebi olarak dopamin ile AA'nın elektrooksidasyon potansiyellerinin oldukça yakın olması gösterilmiştir (Liu vd., 2018). Böylece NiS/rGO kompozit kağıt elektrot kullanılarak AA'nin tayinine dopaminin girişim yaptığı ortaya konmuştur. Diğer bir seçicilik çalışmasında ise meyve suyu numunesi yaklaşık 1/10 oranında $0.1 \mathrm{M}$ pH 7.0 fosfat tampon çözeltisinde seyreltilmiş ve bu şekilde hazırlanmış çözeltide, NiS/rGO kompozit kağıt elektrot üzerinde AA için elde edilmiş CV grafiği Şekil

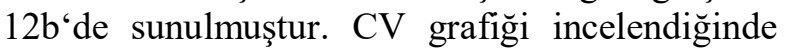
AA'ya ait yükseltgenme pikinin meyve suyu numunesinde bile iyi bir şekilde belirlendiği ve ilave herhangi bir pikin oluşmadığ 1 gösterilmiştir. Böylece hazırlamış olduğumuz kompozit kağıt elektrodun AA tayini için oldukça seçici olduğu belirlenmiştir. 

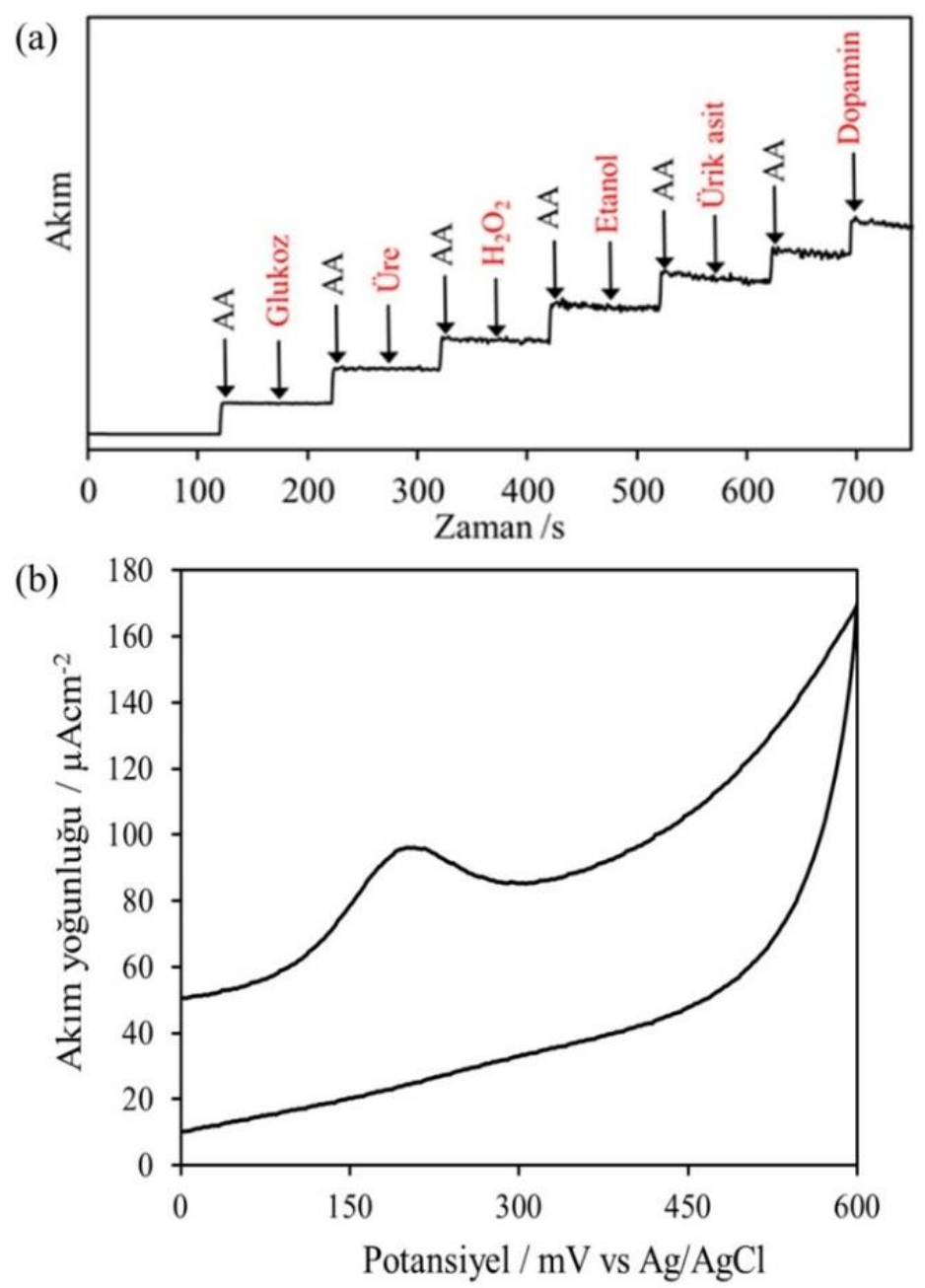

Şekil 12. (a) NiS/rGO kompozit kağıt elektrotuna $0.1 \mathrm{M}$ fosfat tampon çözeltisine (pH 7.0) $50 \mathrm{~s}$ düzenli aralıklar ile ardı ardına aynı derişime sahip AA, glikoz, üre, $\mathrm{H}_{2} \mathrm{O}_{2}$, etanol, ürik asit ve dopamin ilavesi ile elde edilen amperometrik akım-zaman eğrisi (Uygulanan potansiyel: $220 \mathrm{mV}$ ). (b) $0.1 \mathrm{M} \mathrm{pH} 7.0$ fosfat tampon çözeltisinde $1 / 10$ oranında seyreltilerek hazırlanmış meyve suyu numunesine ait NiS/rGO kompozit kağıt elektrot üzerinde elde edilmiş CV grafiği. Tarama hızı: $50 \mathrm{mV} \mathrm{s}^{-1}$

$\mathrm{Bu}$ sonuçlar doğrultusunda $\mathrm{NiS} / \mathrm{rGO}$ kompozit kağıt elektrodun AA'nın elektrokatalitik belirlenmesinde kısmen iyi bir anti-girişim performansına ve seçiciliğe sahip olduğu belirlenmiştir.

Hazırlanan NiS/rGO kompozit kağıt elektrotun gerçek numunelerde AA'nın olarak belirlenmesi için çalışmalar gerçekleştirilmiştir. Gerçek numune analizler için gereç ve yöntem kısımda belirtilen özelliklere sahip izotonik serum numunesi seçilmiş ve standart ilave yöntemi kullanılarak analizler yapılmıştır. Analizler optimum koşullar altında gerçekleştirilmiştir. İzotonik serumu numunelerinde AA olmadığ için başlangıçta belirlenememiştir ardında farklı miktarlarda AA ilave edilmiş ve $\mathrm{NiS} / \mathrm{rGO}$ kompozit kağıt elektrot kullanılarak analizler yapılmıştır. Benzer şekilde AA ilave edilmeden meyve suyu (özellikleri gereç ve yöntem kısmımda belirtilmiş) numunelerinde de AA tayini yapılmıştır. Ardından meyve suyu numunelerine bilinen miktarda AA ilave edilmiş ve yeniden analiz yapılmıştır. Elde edilen sonuçlar Tablo 1'de özetlenmiştir. Analizler sonucunda geri kazanımın \%98.5'den \%102.4'e değiştiği ve her bir numune için \%RSD'nin \%3.02‘den daha az olduğu belirlenmiştir. Elde edilen sonuçlar değerlendirildiğinde hazırlamış olduğumuz NiS/rGO kompozit kağıt elektrodun AA'in gerçek numunelerde tayinin için oldukça uygun ve etkili olduğu belirlenmiştir.

NiS/rGO kompozit kağıt elektrotun hazırlanması ve AA'nın amperometrik tayininde kullanımı ile ilgili herhangi bir çalışma literatürde mevcut değildir. AA'nın amperometrik tayini için $\mathrm{NiS} / \mathrm{rGO}$ kompozit kağıt elektrotunun sensör performansları literatürdeki çalışmalarla karşılaştırılmıştır (Tablo 2). 
Tablo 1. NiS/rGO kompozit kağıt elektrot kullanılarak izotonik serum ve meyve suyu numunelerinde AA'nın belirlenmesi.

\begin{tabular}{|c|c|c|c|c|c|c|}
\hline & & $\begin{array}{l}\text { Başlangıçta tayin } \\
\text { edilen }(\mu \mathrm{M})^{\mathrm{a}}\end{array}$ & $\begin{array}{c}\text { İlave edilen } \\
(\mu \mathrm{M})\end{array}$ & $\begin{array}{c}\text { Sonradan tayin } \\
\text { edilen }^{\mathrm{a}}(\mu \mathrm{M})\end{array}$ & $\begin{array}{c}\text { Geri kazanim } \\
(\%)\end{array}$ & \%RSD \\
\hline & 1 & - & 40 & 38.5 & 98.5 & 1.82 \\
\hline Serum & 2 & - & 80 & 80.8 & 100.8 & 2.25 \\
\hline örnekleri & 3 & - & 160 & 160.2 & 100.2 & 2.17 \\
\hline Meyve & 1 & 10 & 30 & 42.1 & 102.1 & 3.02 \\
\hline suyu & 2 & 12 & 60 & 73.4 & 102.4 & 2.45 \\
\hline
\end{tabular}

NiS/rGO kompozit kağıdın, AA'nın belirlenmesinde önceki çalışmalarla kıyaslandığında nispeten geniş doğrusal aralık ve düşük tayin limiti sergilediği belirlenmiştir. Literatür verileri incelendiğinde AA tayini için daha geniş doğrusal çalışma aralıklarının ve daha düşük tayin limitlerinin elde edildiği çalışmaların olduğu bilinmektedir. Fakat Tablo 2'de sunulan referanslarda kullanilan elektrotlar genellikle cams1 karbon elektrot (Glassy Carbon Electrode,
GCE) gibi kat1 destek materyali üzerinde hazırlanan modifiye elektrotlardır. Bu çalışmanın en önemli farkı esnek, herhangi bir desteğe ihtiyaç durmadan durabilen ve dayanıklı bir malzeme olan NiS/rGO kompozit kağıt elektrot kullanarak AA'nın tayin edilmesidir. Buna ilave olarak hazırlanmış olan NiS/rGO kompozit kağıt elektrodun AA tayinin için oldukça yüksek depolama, tekrar kullanım ve tekrar üretilebilirlik kararlı1ıklarına sahip olduğu da belirlenmiştir.

Tablo 2. NiS/rGO kompozit kağıt elektrotun AA'nın amperometrik tayini için diğer modifiye elektrotlarla karşıllaştırılması.

\begin{tabular}{|c|c|c|c|}
\hline Elektrot materyalleri & Doğrusal aralık $(\mu \mathrm{M})$ & Tayin limiti $(\mu \mathrm{M})$ & Kaynaklar \\
\hline MWCNT-PEDOT/GCE & $100-200$ & 100 & Lin vd., 2010 \\
\hline $\mathrm{Ni} / \mathrm{C} / \mathrm{GCE}$ & $20-2400$ & 5.0 & He vd., 2016 \\
\hline Ni-PANI/GCE & $10-300$ & 7.1 & $\begin{array}{l}\text { Anu-Prathap vd., } \\
2013\end{array}$ \\
\hline $\mathrm{Au} / \mathrm{rGO} / \mathrm{GCE}$ & $240-1500$ & 51 & Wang vd., 2014 \\
\hline $\mathrm{GR} / \mathrm{SnO}_{2} / \mathrm{GCE}$ & $100-1000$ & 100 & Xie vd., 2015 \\
\hline APMCNPE & $0.2-1200$ & 0.08 & Gheibi vd., 2015 \\
\hline $\mathrm{NiO} / \mathrm{NPs} / \mathrm{CPE}$ & $0.5-1000$ & 0.2 & $\begin{array}{l}\text { Karimi-Maleh } \\
\text { vd., } 2014\end{array}$ \\
\hline $\mathrm{NiO} / \mathrm{GR} / \mathrm{GCE}$ & $0.05-1100$ & 0.0167 & Liu vd., 2014 \\
\hline MWCNT/GCE & $10-500$ & 0.0035 & Gupta vd., 2014 \\
\hline $\mathrm{MoS}_{2} \mathrm{PANI} / \mathrm{rGO} / \mathrm{GCE}$ & $50-8000$ & 22 & Li vd., 2019 \\
\hline rGO-ZnO/GCE & $50-2350$ & 3.7 & Zhang vd., 2016 \\
\hline GO-PANI/GCE & $150-105$ & 50 & Bao vd., 2011 \\
\hline NiS/rGO kağıt & $1.0-800$ & 0.7 & $\mathrm{Bu}$ çalışma \\
\hline \multicolumn{4}{|c|}{$\begin{array}{l}\text { GCE: Cams1 karbon elektrot, MWCNT:Çok duvarlı karbon nanotüp, PEDOT: poly(3,4 } \\
\text { etilendioksitiyofen), PANI: Polyanilin, NPs: Nanopartikül, GR: Grafen, APMCNPE: p-aminofenol } \\
\text { modifiye karbon nanotüp bask1 elektrot, NiO: Nikel oksit, } \mathrm{SnO}_{2} \text { : Kalay IV oksit, GO: Grafen oksit, C: } \\
\text { Karbon, Ni: Nikel, Au: Altın }\end{array}$} \\
\hline
\end{tabular}




\section{Sonuç}

Basit bir elektrokimyasal yöntem kullanılarak $\mathrm{NiS} / \mathrm{rGO}$ kompozit kağıt elektrot hazırlanmış ve yapısal, morfolojik ve elektriksel özellikleri farklı teknikler kullanılarak karakterize edilmiştir. NiS/rGO kompozit kağıt elektrodun esnek, serbest durabilen ve kararlı olmasının yanı sıra yüzeyinde bulunan top benzeri NiS nanoyapılarından dolayı oldukça yüksek elektroaktif yüzey alanına sahip olduğu belirlenmiştir. AA'nın amperometrik belirlenmesinde kullanılan NiS/rGO kompozit kağıt elektrodun katalitik performansının oldukça yüksek olduğu ortaya konmuştur. NiS/rGO kompozit kağıdın validasyon paremetreleri incelendiğinde oldukça yüksek depolama, tekrar kullanım ve tekrar üretilebilirlik performanslarına sahip olduğu tespit edilmiştir. Buna ilave olarak, NiS/rGO kompozit kağıt atmosferik koşullarda kimyasal ve fiziksel olarak kararlıdır ve mekanik olarak esnektir. Bu özelliklere sahip olan çalışma konusu sensörün AA'nın kantitatif tayini için farklı uygulamalarda kolayca kullanılabilir olduğu ortaya konmuştur. Gerçekleştirilmiş olan gerçek numune çalışmalarında yüksek duyarlılıkta AA analizine imkan sağlandığı kanıtlanmıştır.

\section{Kaynaklar}

Aksu, Z. ve Alanyalıoğlu, M., 2017. Fabrication of free-standing reduced graphene oxide composite papers doped with different dyes and comparison of their electrochemical performance for electrocatalytical oxidation of nitrite. Electrochimica Acta, 258,1376-1386.

Anu Prathap, M.U. ve Srivastava, R., 2013. Tailoring properties of polyaniline for simultaneous determination of a quaternary mixture of ascorbic acid, dopamine, uric acid, and tryptophan. Sensors and Actuators B, 177, 239250.

Arumugam, N. ve Kim J.S., 2018. Quantum dots attached to graphene oxide for sensitive detection of ascorbic acid in aqueous solutions. Materials Science and Engineering C, 92, 720725 .

Bao, Y., Song, J., Mao, Y., Han, D., Yang, F., Niu, L. ve Ivaska, A., 2011. Graphene Oxide-Templated Polyaniline Microsheets toward Simultaneous Electrochemical Determination of AA/DA/UA. Electroanalysis, 23, 4, 878-884.

Chen, H., Liu Y., Li, H., Zhang, Y. ve Yao, S., 2019. Non-oxidation reduction strategy for highly selective detection of ascorbic acid with dualratio fluorescence and colorimetric signals. Sensors and Actuators: B. Chemical, 281, 983988.
Chen, J., Ge, J., Zhang, L., Li, Z., Li, J., Sun, Y. ve Qu, L., 2016. Reduced graphene oxide nanosheets functionalized with poly(styrene sulfonate) as a peroxidase mimetic in a colorimetric assay for ascorbic acid. Microchimica Acta, 183,18471853.

Dağc1, K. ve Alanyalığlu, M., 2016. Preparation of Free-Standing and Flexible Graphene/Ag Nanoparticles/Poly(pyronin Y) Hybrid Paper Electrode for Amperometric Determination of Nitrite. ACS Applied Materials Interfaces, 8, 2713-2722.

Dagci Kiransan, K., Topcu, E. ve Alanyalioğlu, M., 2016. Surface-Confined Electropolymerization of Pyronin Y in the Graphene Composite Paper Structure for Ampeormetric Determination of Dopamine. Journal of Applied Polymer Science, 45139,1-10.

Dağcı Kıranşan, K. ve Topçu, E., 2018. Free-standing and Flexible $\mathrm{MoS}_{2} / \mathrm{rGO}$ Paper Electrode for Amperometric Detection of Folic Acid, Electroanalysis. 30, 810-818.

Dağcı Kiranşan, K., Aksoy, M. ve Topçu, E., 2018. Flexible and freestanding catalase$\mathrm{Fe}_{3} \mathrm{O}_{4} /$ reduced graphene oxide paper: Enzymatic hydrogen peroxide sensor applications, Materials Research Bulletin. 106, 57-65.

Gheibi, S., Karimi-Maleh, H., Khalilzadeh, M.A. ve Bagheri, H., 2015. A new voltammetric sensor for electrocatalytic determination of vitamin $\mathrm{C}$ in fruit juices and fresh vegetable juice using modified multi-wall carbon nanotubes paste electrode. Journal of Food Science Technology, 52(1), 276-284.

Gupta, V.K., Jain, A.K. ve Shoora, S.K., 2013. Multiwall carbon nanotube modified glassy carbon electrode as voltammetric sensor for the simultaneous determination of ascorbic acid and caffeine. Electrochimica Acta, 93, 248-253.

Harraz, F.A., Faisal, M., Al-Salami, A.E., El-Toni, A.M., Almadiy, A.A., Al-Sayari, S.A. ve AlAssiri, M.S., 2019. Silver nanoparticles decorated stain-etched mesoporous silicon for sensitive, selective detection of ascorbic acid. Materials Letters, 234, 96-100.

He, W., Ding, Y., Zhang, W., Ji, L., Zhang, X. ve Yang, F., 2016. A highly sensitive sensor for simultaneous determination of ascorbic acid, dopamine and uric acid based on ultra-small $\mathrm{Ni}$ nanoparticles. Journal of Electroanalytical Chemistry, 775, 205-211.

Hummers, W.S ve Offeman, R.E., 1958. Preparation of graphitic oxide.Journal of the American Chemical Society, 80, 1339-1339. 
Huo, J., Wu, J., Zheng, M., Tu, Y. ve Lan, Z., 2015. Effect of ammonia on electrodeposition of cobalt sulfide and nickel sulfide counter electrodes for dye-sensitized solar cells. Electrochimica Acta, 180,574-580.

Kaplan, İ.H., Dağcı, K. ve Alanyalığlu, M., 2010. Nucleation and Growth Mechanism of Electropolymerization of Methylene Blue: The Effect of Preparation Potential on Poly(methylene blue) Structure. Electroanalysis, 22, 2694-2701.

Karimi-Maleh, H., Moazampour, M., Yoosefian, M., Sanati, A.L. Tahernejad-Javazmi, F. ve Mahani, M., 2014. An Electrochemical Nanosensor for Simultaneous Voltammetric Determination of Ascorbic Acid and Sudan I in Food Samples. Food Analytical Methods, 7, 2169-2176.

Kim, W.S., Dahlgren, R.L., Moroz, L.L ve Sweedler, J.V., 2002. Ascorbic acid assays of individual neurons and neuronal tissues using capillary electrophoresis with laserinduced fluorescence detection. Analytical Chemistry, 74, 5614-5620.

Koblová, P., Sklenářová, H., Brabcová, I. ve Solich, P., 2012. Development and validation of a rapid HPLC method for the determination of ascorbic acid, phenylephrine, paracetamol and caffeine using a monolithic column. Analttical Methods, $4,1588-1591$.

Kumar, M.A., Lakshminarayanan, V. ve Ramamurthy, S.S., 2019. Platinum nanoparticles decorated graphene-modified glassy carbon electrode toward the electrochemical determination of ascorbic acid, dopamine, and paracetamol. Comptes Rendus Chimie, 22, 58-72.

Li, Y., Zhang, H.X., Liu, F.T., Dong, X.F., Li, X. ve Wang, C.W., 2019. New design of oriented NiS nanoflower arrays as platinum-free electrode for high-efficient dye-sensitized solar cells. Superlattices and Microstructures, 125, 66-71.

Lin, K.C., Tsai, T.H. ve Chen, S.M., 2010. Performing enzyme-free $\mathrm{H}_{2} \mathrm{O}_{2}$ biosensor and simultaneous determination for AA, DA, and UA by MWCNT-PEDOT film. Biosensors and Bioelectronics, 26, 608-614.

Liu, B., Luo, L., Ding, Y., Si, X., Wei, Y., Ouyang, X. ve $\mathrm{Xu}, \mathrm{D}$., 2014. Differential pulse voltammetric determination of ascorbic acid in the presence of folic acid at electro-deposited $\mathrm{NiO} /$ graphene composite film modified electrode. Electrochimica Acta, 142, 336-342.

Liu, H., Li, N., Zhang, H., Zhang, F. ve Su, X., 2018. A simple and convenient fluorescent strategy for the highly sensitive detection of dopamine and ascorbic acid based on graphene quantum dots. Talanta, 189, 190-195.
Luo, P., Zhang, H., Liu, L., Zhang, Y., Deng, J., Xu, C., Hu, N. ve Wang, Y., 2017. Targeted Synthesis of Unique Nickel Sulfide $\left(\mathrm{NiS}, \mathrm{NiS}_{2}\right)$ Microarchitectures and the Applications for the Enhanced Water Splitting System, ACS Applied Materials Interfaces. 9, 2500-2508.

Ma, Z., Yuan, X., Zhang, Z., Mei, D., Li, L., Ma, Z.F., Zhang, L., Yang, J. ve Zhang, J., 2015. Novel Flower-like Nickel Sulfide as an Efficient Electrocatalyst for Nonaqueous Lithium-Air Batteries. Scientific Reports, 5, 18199.

May, B.M.M., Parani, S. ve Oluwafemi, O.S.,2019. Detection of ascorbic acid using green synthesized $\mathrm{AgInS}_{2}$ quantum dots. Materials Letters, 236, 432-435.

Peng, J., Ling, J., Zhang, X.Q., Zhang, L.Y., Cao, Q.E. ve Ding, Z.T., 2015. A rapid, sensitive and selective colorimetric method for detection of ascorbic acid. Sensors and Actuators B.Chemical, 221,708-716.

Rather, M.A., Bhat, S.A., Pandit S.A., Rather, G.M., Khan, K.Z. ve Bhat M.A., 2017. Imidazolium Based Surface Active Ionic Liquids as Novel Micellar Media for Simultaneous and Sensitive Electrochemical Detection of Dopamine and Ascorbic Acid. Electroanalysis, 29, 1772-1782.

Salavati-Niasari, M., Davar, F. ve Emadi, H., 2010. Hierarchical Nanostructured Nickel Sulfide Architectures Through Simple Hydrothermal Method in the Presence of Thioglycolic Acid. Chalcogenide Letters, 7, 12, 647-655.

Sun, C.L., Chang, C.T., Lee, H.H., Zhou, J., Wang, J., Sham, T.K. ve Pong, W.F., 2011. Microwaveassisted synthesis of a core-shell MWCNT/GONR heterostructure for the electrochemical detection of ascorbic acid, dopamine, and uric acid. ACS Nano 5, 77887795.

Thearle R.A., Latiff, N.M., Sofer, Z., Mazanek, V. ve Pumera M., 2017. Boron and Nitrogen Doped Graphene via Microwave Exfoliation for Simultaneous Electrochemical Detection of Ascorbic Acid, Dopamine and Uric Acid. Electroanalysis, 29, 45-50.

Topçu, E. ve Dağcı Kıranşan, K., 2018. Flexible and Free-standing PtNLs- $\mathrm{MoS}_{2} /$ Reduced Graphene Oxide Composite Paper: A High-Performance Rolled Paper Catalyst for Hydrogen Evolution Reaction. ChemistrySelect, 3, 5941-5949.

Topçu, E., Dağcı, K. ve Alanyalıŏlu, M., 2016. Freestanding Graphene/Poly(methylene blue)/AgNPs Composite Paper for Electrochemical Sensing of NADH. Electroanalysis, 28, 1-13. 
Tran, V.C., Sahoo, S. ve Shim, J.J., 2018. Roomtemperature synthesis of NiS hollow spheres on nickel foam for high-performance supercapacitor electrodes. Materials Letters, 210, 105-108.

Wang, C., Du, J., Wang, H., Zou, C., Jiang, F., Yang, P. ve Du, Y., 2014. A facile electrochemical sensor based on reduced graphene oxide and $\mathrm{Au}$ nanoplates modified glassy carbon electrode for simultaneous detection of ascorbic acid, dopamine and uric acid. Sensors and Actuators B, 204, 302-309.

Wang, Z., Teng, X. ve Lu, C., 2012. Carbonate interlayered hydrotalcites-enhanced peroxynitrous acid chemiluminescence for high selectivity sensing of ascorbic acid. Analyst, 137,1876-1881.

Xie, H., Fu, Y., Zhang, Q., Yan,K., Yang, R., Mao, K., Chu,P. K., Liu, L. ve Wu, X., 2019.Selective and high-sensitive label-free detection of ascorbic acid by carbon nitride quantum dots with intense fluorescence from lone pair states. Talanta, 196, 530-536.

Xie, Y.L., Yuan, J., Ye, H.L., Song, P. ve Hu, S.Q., 2015. Facile ultrasonic synthesis of graphene $/ \mathrm{SnO}_{2}$ nanocomposite and its application to the simultaneous electrochemical determination of dopamine, ascorbic acid, and uric acid. Journal of Electroanalytical Chemistry, 749, 26-30.

Zhang, X., Zhang, Y.C. ve Ma, L.X., 2016. One-pot facile fabrication of graphene-zinc oxide composite and its enhanced sensitivity for simultaneous electrochemical detection ofascorbic acid, dopamine and uric acid. Sensors and Actuators B: Chemical, 227, 488496. 